\title{
FOREIGN BANKS AND INTERNATIONAL TRANSMISSION OF MONETARY POLICY: EVIDENCE FROM THE SYNDICATED LOAN MARKET
}

\author{
Asli Demirgüç-Kunt \\ Bálint I. Horváth \\ Harry Huizinga \\ Accounting and Finance \\ Discussion Paper 17 / 6 \\ 25 January 2017
}

\section{BRISTOL}

School of Economics, Finance and Management

University of Bristol

8 Woodland Road

Bristol BS8 1TN

United Kingdom 


\title{
Foreign banks and International Transmission of Monetary Policy: Evidence from the Syndicated Loan Market ${ }^{1}$
}

\author{
Asli Demirgüç-Kunt \\ World Bank \\ Bálint L. Horváth \\ University of Bristol \\ Harry Huizinga \\ Tilburg University and CEPR
}

\begin{abstract}
This paper uses loan-level data from 124 countries over 1995-2015 to examine the transmission of monetary policy through the cross-border syndicated loan market. The results show that the expansion of monetary policy increases cross-border credit supply especially to weaker firms. However, greater foreign bank presence in the borrower country appears to reduce the potentially destabilizing impact of lower policy interest rates on cross-border lending, as it attenuates increases in loan volume and maturity while magnifying increases in collateralization and covenant use. The mitigating effect of foreign banking presence in the borrowing country on the transmission of monetary policy is robust to controlling for borrower-country economic and financial development, and a range of borrower and lender country policies and institutions, including the strength of bank regulation and supervision, exchange rate flexibility, and restrictions on capital flows. The findings qualify the characterization of international banks as sources of credit instability, and suggest that foreign bank entry can improve the stability of cross-border credit in the face of international monetary policy shocks.
\end{abstract}

Keywords: Cross-border lending; Monetary transmission; Banking FDI; Bank regulation; Capital controls

JEL classification: E44; E52; F34; F38; F42; G15; G20

\footnotetext{
${ }^{1}$ This paper's findings, interpretations, and conclusions are entirely those of the authors and do not necessarily represent the views of the World Bank, its Executive Directors, or the countries they represent. We thank Mintra Dwarkasing, Jan Pieter Krahnen and seminar participants at the Luxembourg School of Finance, the Portsmouth-Fordham Conference on Banking \& Finance, the 2nd Empirical Financial Intermediation Workshop in Brussels, the 25th International Rome Conference on Money, Banking and Finance in Rome, the Financial Intermediation in Emerging Markets conference in Cape Town, and the 4th Bordeaux Workshop in International Economics and Finance for useful comments.
} 


\section{Introduction}

International banks operate in foreign countries through local affiliates and crossborder lending. They offer opportunities to promote economic development as they bring in capital, liquidity, expertise, and new technologies, which can promote greater competition and improved resource allocation. International banks also have a risk sharing role which implies that they help host countries stabilize their credit supply during a local downturn and that they shift resources back to the home country when conditions there worsen. This risk sharing role can also expose host countries to greater volatility from time to time, and in the aftermath of the financial crisis, academics and policymakers have voiced concerns that monetary policies pursued by lending countries can have negative spillovers on emerging markets' financial stability (Rey, 2013; Rajan, 2014; Fischer, 2014).

Consistent with these arguments, recent studies find a significant international transmission of monetary policy through its effect on the supply of cross-border loans. Using a VAR framework, Bruno and Shin (2015a) estimate that a contractionary shock to US monetary policy leads to a decrease in cross-border bank lending, as international banks reduce their leverage. Micro studies provide additional evidence on how international monetary policy shocks affect bank lending to borrowers in particular countries. Morais, Peydró and Ruiz (2015), for instance, investigate the impact of monetary policy in three financial centers (the US, the UK, and the Eurozone) on the provision of credit by subsidiaries of banks from these centers to corporations in Mexico, finding a positive supply effect of a lower monetary policy interest rate, especially towards riskier borrowers.

The impact of monetary policy on the international supply of bank credit, however, is likely to differ not only across borrowers with different risk profiles, but also across different borrower and lender countries, depending on their level of economic and financial development and on a range of economic policies and institutions. The transmission of 
monetary policy, for instance, is potentially affected by the foreign bank penetration in the borrower country (c.f. De Haas and Van Lelyveld, 2006; Claessens and Van Horen, 2012; Ongena et al., 2015), the quality of bank supervision and regulation in borrower and lender countries (Ongena et al., 2013), the exchange rate system of the borrower country, and also the existence of restrictions on capital inflows into the borrower country (Rey, 2016).

In this paper, we investigate the role of foreign banks in the international transmission of monetary policy through the cross-border syndicated loan market using loan level data in 124 countries over the $1995-2015$ period. Use of loan level data for multiple lender and borrower countries has two main advantages. First, including borrower*time fixed effects allows us to control for time-varying loan demand at the individual borrower level. Second, examining multiple countries allows us to investigate the impact of varying bower and lender country policies and institutions on the transmission of lender-country monetary policy. Identification of an effect of monetary policy on loan supply volume and other loan terms is achieved by considering variation in the monetary policies relevant for banks in different countries that lend to the same firm in the same time period.

Our main finding is that the transmission of lender-country monetary policy through the cross-border syndicated loan market depends importantly on the existence of banking FDI in the borrowing country. Specifically, greater foreign banking presence reduces the sensitivity of the international loan supply to lender-country policy interest rates. This may to some extent reflect that an international bank with a local presence in the borrower country can substitute local funding for more expensive international funding if the lender-country monetary policy interest rate rises. Consistent with this, we find that the mitigating impact of banking FDI on the international transmission of monetary policy to loan volume is weaker if the borrower-country policy interest rate is higher, since this reduces the ability of a multinational bank to substitute borrower-country funding for lender-country funding. Our 
findings are robust to controlling for a range of country-level institutional and policy variables, such as the strength of bank regulation and supervision, exchange rate flexibility and restrictions on capital flows.

Our main contribution in this paper is to investigate the role of the structure of the international banking market in the international transmission of monetary policy. The literature on the effect of monetary policy on cross-border lending builds on several papers investigating the bank lending channel domestically. Bank balance sheet strength (Jiménez et al., 2012a; Jiménez et al., 2014b; Gambacorta, 2005) and bank risk (Altunbas et al., 2010) have been shown to affect the impact of monetary policy on bank credit supply. Further, low monetary policy rates induce risk taking (e.g. Jiménez et al., 2014a; Ioannidou et al. 2015), and there is evidence of a portfolio rebalancing channel as well (den Haan et al., 2007).

The paper most closely related to ours is Cerutti, Claessens and Ratnovski (2014), who study drivers of cross-border bank flows using aggregate, bilateral credit flow data published by the BIS. They find that these flows are largely driven by global factors (e.g. VIX volatility and the slope of the US yield curve). These authors also find that the transmission of monetary policy to cross-border credit is affected by certain borrowing country policies, such as exchange rate flexibility, capital controls and bank regulation. Our paper differs from Cerutti et al. (2014) in several ways. First, we control for credit demand at the borrower firm level, so our findings are more likely to reflect supply side conditions. Second, our main interest is the effect of monetary policy in the relevant lender countries on cross-border lending. Finally, we provide a more comprehensive picture of cross-border lending by also studying non-volume loan terms.

Our paper is also related to the literature showing how banks reduce cross-border lending in response to non-policy funding shocks at home. Peek and Rosengren (1997), in particular, exploit the Japanese stock market crash in the 1990s, while various papers look at 
the effect of the global financial crisis on cross-border lending (Aiyar, 2012; Cetorelli and Goldberg 2011; Cetorelli and Goldberg, 2012b; Gambacorta and Marques-Ibanez, 2011; Giannetti and Laeven, 2012a,b; de Haas and van Horen, 2011; de Haas and van Horen, 2013; Ivashina et al., 2015).

Our results are broadly consistent with Morais et al. (2015) who find that monetary easing in the US, the UK and the Eurozone lowers loan rates and lengthen loan maturities in Mexico, with an offsetting risk-reducing effect through more stringent collateral requirements. Consistent with this, Miranda-Agrippino and Rey (2015) find evidence of a "global financial cycle", showing that cross-border credit flows are to a large extent driven by US monetary policy. Several additional papers (Kim, 2001; Bruno and Shin, 2015a; Temesvary et al., 2015) also find that cross-border lending increases when US monetary policy eases. Furthermore, Cetorelli and Goldberg (2012a) show that US global banks actively reallocate capital from their foreign affiliates to their headquarters when US monetary policy tightens.

All of these various studies show a potentially destabilizing role for international banks, as monetary policy changes in their countries of residence are transmitted as international credit supply shocks to borrowing countries. Consistent with a destabilizing role for international banks, Bertay, Demirguc-Kunt and Huizinga (2015) also find that lending by foreign-owned banks in a country tends to be relatively procyclical compared to domestic banks. This paper importantly qualifies the picture that emerges of international banks as sources of credit instability, since we find that foreign banking presence in the form of banking FDI reduces the sensitivity of cross-border loan supply to lender-country monetary policy. Cross-border credit is an important source of funding for many countries, and for these countries additional banking FDI may well serve to stabilize the overall supply of credit. 
In the remainder, section 2 discusses the data. Section 3 presents evidence of the transmission of monetary policy to loan volumes and other credit terms, and on how this transmission depends on borrower creditworthiness. Section 4 considers the role of banking FDI and other country-level institutional and policy variables in the international transmission of monetary policy. Section 5 concludes.

\section{Data}

Our cross-border lending data come from the Loan Pricing Corporation's (LPC) Dealscan database, which contains detailed data on syndicated loans originated all around the world. The database contains information on individual loan volume, pricing, as well as other loan terms and conditions. LPC collects this information from SEC filings and public documents, loan syndicators and other sources. Our data set comprises lenders in 50 countries, and borrowing non-financial firms in 124 countries over the 1995-2015 period. Table A1 in the appendix shows the number of lenders and loans by lender country, while the number of borrowers and loans by borrower country is shown in Table A2.

A feature of the data is that loans are organized by packages and facilities. A package is a loan agreement signed by a borrower and one or more lenders, and each of them may contain one or more facilities. The basic level of observation in Dealscan is a facility. A further characteristic of syndicated loans is that lenders may assume different roles in a deal. Most importantly, lead arrangers are responsible for negotiating the terms with borrowers, and they are also responsible for monitoring borrowers. Several papers provide extensive information about the syndicated loan market as well as LPC's Dealscan, see e.g. Chava and Roberts (2008).

As a first main independent variable we create Volume, which is the natural logarithm of the dollar amount of a bank's share in syndicated lending aggregated at the borrower- 
lender-time level (see Table A3 in the appendix for variable descriptions and data sources). The sample includes only non-financial borrowing companies. Throughout the analysis we use a monthly frequency in the time series dimension. If the information about a bank's share in a loan is missing, the loan is discarded in constructing the volume variable. In addition, we exclude the years before 1995, because Dealscan contains significantly fewer observations in these years. Our sample spans the period from January 1995 to March 2015. Since we focus on cross-border lending, we also exclude observations if the borrower's and lender's country of location coincide. Following the literature, e.g. de Haas and van Horen (2012), we define the nationality of a bank based on the location of the ultimate parent. Table 1 shows that the average borrower-lender loan volume is 55.6 million US dollars and ranges between USD 1 and 410 million. As seen in Figure 1, the total volume of cross-border syndicated loans rose rapidly before the crisis, fell back substantially during 2008-2009, and subsequently recovered to pre-crisis levels towards the end of the sample period.

We also examine various non-volume terms of the loan contracts. First, Maturity is the maturity of a facility in months. In Table 1 we can see that the average maturity of loans in our sample is 60.6 months, or about 5 years. Next, Spread is the loan spread over the reference rate in basis points for drawn credit of a facility with a sample average of 245.7 basis points. The next loan characteristic variable is Collateral, which is a dummy variable indicating that a loan is collateralized. ${ }^{2}$ Table 1 reports that about $81.7 \%$ of loans are collateralized in our sample. Finally, Covenant is a dummy variable indicating that there is a net worth or financial ratio covenant in the loan contract. About $29 \%$ of loans to nonfinancial companies have at least one of these covenants. Unlike the volume regressions, other loan term regressions are at the level of facility (in the case of Maturity, Spread and

\footnotetext{
${ }^{2}$ The observation is dropped in collateral regressions if the "secured" field in Dealscan is empty.
} 
Collateral) or package (in the case of Covenant). Since a loan may have several lenders, we aggregate lender characteristics by taking their unweighted average, including the characteristics of the countries where lenders reside. ${ }^{3}$

We matched Dealscan with monetary policy rates from the International Financial Statistics (IFS) database of the IMF. Our main dependent variable, IR, is the lender-country central bank policy rate (replaced by the discount rate at which commercial banks can borrow from the central bank against eligible securities in case of a few countries where the central bank policy rate data was missing). Similarly, IR (Borrower) is the borrower-country central bank policy rate or the discount rate. In some specifications we use deviations from an estimated Taylor rule type monetary policy rate for the lender country as an alternative measure of the stance of monetary policy in this country. To calculate this variable, called Taylor residual, we regress the monetary policy rate, IR, on real GDP growth and the inflation rate separately for each country, and then take the errors from these regressions. According to Table 1, the average monetary policy rate, IR, over the whole sample period was $2.48 \%$, while Taylor residuals averaged -0.005 . An additional lender-country monetary policy variable is $\mathrm{QE}$, which indicates that a quantitative easing program was in place in a lender country in a given month. This variable reflects that the Fed, the European Central Bank, Bank of England, and the Bank of Japan implemented various quantitative easing programs at different points in time (see the appendix for the exact dates ${ }^{4}$ ) in efforts to

\footnotetext{
${ }^{3}$ By taking the unweighted average of lender characteristics we avoid the problem of missing loan volume contributions. For example, using non-missing loan shares as weights would reduce the number of loans from 92,191 to 18,133 in the first maturity regression in Table 4. In addition, unweighted averages are less affected by endogenous changes in loan contributions.

${ }^{4}$ In the reported regressions we do not distinguish between the different rounds of QE in the United States. The results are robust, however, to specifying the QE to reflect the three periods corresponding to QE1, QE2 and QE3, as follows: December 2008 to March 2010, November 2010 to June 2011, and September 2012 to December 2013.
} 
simulate depressed and stagnant economies. CPI and GDP stand for lender-country consumer price inflation and real GDP growth and are obtained from the IFS.

Next, we also matched Dealscan with Worldscope to obtain data on a borrower's equity-to-assets ratio (Borrower E/A). ${ }^{5}$ This variable is calculated as the lagged book value of common equity over total assets. To exclude the impact of outliers we winsorized all continuous borrower and loan level variables (i.e., Volume, Spread, Maturity and Borrower E/A) at the 1st and 99th percentiles. After this adjustment the average borrower equity-toassets ratio is 0.387 .

Next, several variables capture the relationships that international banks have developed with borrower countries through the ownership of local banks or through the prior provision of syndicated loans. Foreign-Owned Banks, borrower represents the assets of foreign-owned banks located in the borrower country as a share of total banking system assets (this variable is taken from Barth et al., 2013). On average, foreign-owned banks hold $16.5 \%$ of banking system assets in borrower countries. Alternatively, FDI is the number of subsidiaries in the borrower country owned by banks in the lender country based on data collected by Claessens and van Horen (2015). The average number of foreign-owned banks in a lender country-borrower country relationship is 1.6. A bank's own experience in the borrowing country is captured by the experience variable, which is the natural logarithm of 1 + the number of loans extended by the relevant lender in the country of the borrower in the three years prior to the loan. In addition, subsidiaries is a dummy variable that equals one if the lender company has at least one subsidiary in the borrower country during the sample period and it is zero otherwise. The subsidiaries variable has a mean of 0.7 .

\footnotetext{
${ }^{5}$ We thank Ferreira and Matos (2012) for sharing their link between Dealscan and Worldscope identifiers.
} 
Next, we consider a set of bank regulatory variables for the borrower and lender countries (from Barth et al., 2013) as potential determinants of syndicated loan volume. Official supervisory power, borrower (lender), measures the extent to which the supervisory authorities in the borrower's (lender's) country have the authority to take specific actions to prevent and correct problems. This variable ranges between 0 and 16, with higher values indicating greater power, and has a mean of 11.7 in borrowers' countries and 10.2 in lenders' countries. Overall capital stringency, borrower (lender), is a variable that measures whether the capital requirement in the borrower's (lender's) country reflects certain risk elements and deducts certain market value losses from capital before minimum capital adequacy is determined. This variable is an index ranging between 0 and 7, with higher values indicating greater stringency. Overall capital stringency, borrower (lender) has a sample mean of 4.4 (4.3). As a final regulatory variable, Overall restrictions on banking activities, borrower (lender) measures the extent to which banks in the borrower's (lender's) country can engage in securities, insurance and real estate activities. This variable ranges between 3 and 12, with higher values indicating more restrictions; the average Overall restrictions on banking activities index is 7.2 for borrower countries, and 6.1 for lender countries.

The next country characteristic we include in the regressions is ER flexibility, which is a dummy variable indicating that a borrower's country has a flexible exchange rate regime. In particular, it takes the value of one if a country's exchange rate regime falls in one of the following categories in the database compiled by Ilzetzky, Reinhart and Rogoff (2011): preannounced crawling band that is wider than or equal to $+/-2 \%$; de facto crawling band that is narrower than or equal to $+/-5 \%$; moving band that is narrower than or equal to $+/-2 \%$ (i.e., allows for both appreciation and depreciation over time); managed floating; and freely floating. Table 1 shows that $78.5 \%$ of borrowers are located in countries with flexible exchange rates. Next, Credit constraints (in), is a dummy variable indicating the presence of 
restrictions on the inflow of commercial credit in the country of the borrower based on the data from Fernández, Klein, Rebucci, Schindler and Uribe (2015). A share of $14.6 \%$ of borrowers face credit constraints on credit inflows into their countries.

In some specifications, we control for proxies of economic and financial development. Among these, GDP per capita is GDP per capita calculated at constant 2005 US dollar prices with a sample mean of 31,363 US dollars. Next, Credit is domestic credit to the private sector by banks as a percentage of GDP with a mean of $81.8 \%$; Domestic credit is domestic credit provided by the financial sector relative to GDP with a mean of $153.1 \%$; Market cap is the market capitalization of listed companies relative to GDP with a mean of $115.9 \%$; and Turnover ratio is the total value of shares traded during the period as a percentage of the average market capitalization for the period with a mean of $119.3 \%$. These variables are from the WDI database. Finally, the rate of inflation and the rate of GDP growth are macroeconomic control variables.

\section{The transmission of monetary policy and borrower creditworthiness}

This section presents empirical evidence of the impact of lender-country monetary policy on the volume of cross-border syndicated lending and on other credit terms. We specifically present results on how his transmission depends on borrower creditworthiness. Loan volume and other credit terms are considered in turn.

\subsection{Loan volumes}

In the loan volume regressions, the dependent variable is the logarithm of the amount of cross-border lending to a particular firm by a particular bank. The regressions include borrower*time fixed effects to control for variation in firm-level loan demand. The main monetary policy variable is the lender-country policy interest rate, IR. The inclusion of borrower*time fixed effects implies that we can identify the impact of the lender-country 
monetary policy interest rate on the supply of credit from banks in different lender countries. Identification relies on variation in policy interest rates among credit countries in a particular month. The regressions in addition include lender fixed effects to control for invariant lender characteristics, for instance a lender's general proclivity to provide cross-border syndicated lending. The rates of inflation and real GDP growth in the lender country are added as control variables. Errors are clustered at the lender company and borrower country levels to allow for commonality in shocks to a bank's lending to firms in a particular borrowing country.

Table 2 presents the basic results. In regression 1, the policy interest rate obtains a negative coefficient suggesting that a lower policy interest rate increases credit supply, but the coefficient is statistically insignificant. Regression 2 includes an interaction of the policy interest rate with the borrowing firm's equity-to-assets ratio as an index of its creditworthiness. In this regression, the policy interest rate and its interaction with equity-toassets obtain negative and positive coefficients that are both significant at $10 \%$. These results suggest that a lower policy interest rate causes banks to increase credit, especially to riskier borrowers.

In recent years central banks have actively conducted nonconventional monetary policies, most importantly in the form of asset purchases that expanded the money supply and also central banks' balance sheets. The Federal Reserve, for instance, started a program of quantitative easing in January 2009. Next, we control for such policies by including a dummy variable $(\mathrm{QE})$ that distinguishes periods of quantitative easing by major lender-country central banks. Specifically, we additionally include the QE variable in regressions 1-2 of Table 2, and report the results as regressions 3-4.

In regression 3, the IR and QE variables obtain coefficients of -0.818 and -0.0713 that are significant at $5 \%$ and $1 \%$, respectively. The estimated coefficient of -0.818 for the IR 
variable suggests that a reduction in the monetary policy rate by 1 percentage point increases cross-border lending supply by $0.818 \%$, which is a sizeable effect and is well within the range of $0.3-3.7 \%$ that Morais et al. (2015) find for banks located in the US, Euro area, or the UK. All the same, changes in monetary policy interest rates can explain only a small part of the overall variation in cross-border lending, as a one-standard-deviation increase in the monetary policy rate of 0.0214 (from Table 1) reduces cross-border lending by $1.5 \%$ $(=0.0214 *-0.818 / 1.162)$ of its standard deviation. The negative estimated coefficient for the QE variable is likely to reflect that central banks undertook quantitative easing at times of economic weakness and bank fragility. Hence, the QE variable de facto is a dummy variable that signals economic and financial crisis and hence is associated with lower lending volumes.

In regression 4, the magnitudes of the estimated coefficients for the IR variable and its interaction with borrower capitalization are similar to those of the corresponding coefficients in regression 2, but controlling for crisis periods associated with $\mathrm{QE}$ allows the coefficients to be estimated more precisely: the coefficient for IR is significant at $1 \%$, and the coefficient for $\mathrm{IR} *$ Borrower E/A is significant at $5 \%$. In this regression, QE has a negative and significant coefficient.

Overall the results of Table 2 indicate that the supply of cross-border loans is negatively related to lender-country policy interest rates, especially for highly leveraged borrowers, and that cross-border loan supply was lower in periods when lending-country central banks were implementing a program of quantitative easing.

Policy interest rates in lender countries can reasonably be assumed to be exogenous to economic developments in foreign borrower countries. All the same, policy interest rates that reflect economic developments in lender countries may be correlated with economic developments in borrower countries to the extent that business cycles are correlated across 
countries. Such a potential correlation, however, does not pose a problem for our identification strategy, as we control for borrower-country economic conditions by including borrower*time fixed effects.

Somewhat less straightforwardly, the business cycle in lender countries could simultaneously affect lender-country policy interest rates and the demand for syndicated loans from a particular lender country in case there are perceived to be synergies between the provision of syndicated loans by banks from that lender country and the provision of trade credit by the same banks in order to finance business-cycle dependent trade between the pertinent borrower and lender countries. To counter this potential challenge to our identification strategy, we next replace the actual lender-country policy interest rate by the component of the policy interest rate that is exogenous to the lender-country business cycle, estimated as the Taylor-rule residual of regressions of the policy interest rates on lendercountry GDP growth and inflation rates.

Table 3 presents the results of regressions including the Taylor residual that are otherwise analogous to the regressions of Table 2 . In regressions 2,3 and 4 , the IR variable obtains negative coefficients that are significant at $1 \%$, while in regressions 2 and 4 the interaction of IR with borrower capitalization obtains positive coefficients that are similarly significant. In regressions 3-4, the QE variable receives negative and significant coefficients. Overall, the results of Table 3 confirm a negative impact of the lender country interest rate variable on cross-border credit supply especially to highly leveraged borrowers in line with the results of Table 2 .

\subsection{Non-volume credit terms}

If credit were homogeneous, then a credit supply increase triggered by lower policy interest rates would simply result in higher credit volume and a lower interest rate as measured by the interest spread. Cross-border syndicated loans, however, are not only 
characterized by their volume and their spread, but also by other credit terms such as loan maturity, whether a loan is collateralized, and whether the loan contract includes covenants based on, for example, net worth or financial ratios. Borrowers and lenders have different preferences of potential combinations of these various credit terms, and it is generally unclear how lower policy interest rates will affect any one of these individual credit terms. If lower policy interest rates give rise to longer maturity loans, then this may, for instance, be accompanied by higher spreads, as longer-term loans generally command higher spreads. Similarly, if spreads fall, then covenant use may increase in order to compensate lenders for the lower spreads. This subsection presents empirical evidence on how lender-country policy interest rates affect several key non-volume credit terms: loan maturity, the spread, whether a loan is collateralized, and whether the loan contract contains a net worth or financial ratio covenant.

Table 4 presents the results. The regressions include borrower country-industry*time fixed effects to control for varying loan demand (with industries defined at the 2-digit SIC level), and errors are clustered at the borrower country level. Since all lenders face the same terms for a given loan and most borrowers have only one loan in a month we cannot include borrower-time fixed effects in the regressions. In the maturity regression 1, the policy interest rate obtains a coefficient that is negative and significant. This suggests that a lower policy interest rate may cause lenders to take on additional credit risk, as longer-maturity loans tend to be riskier. In regression 2 , we include an interaction term of the policy interest rate and the borrower's equity-to-assets ratio to test for a potentially different impact of the policy interest rate change on the loan maturity offered to borrowers with different capitalization rates. This interaction term obtains a coefficient that is positive and insignificant.

Turning to the spread, we see that the policy interest rate has a negative and significant coefficient in regression 3, perhaps because of the increased risk associated with 
lending at longer maturities as evident from regression 1 . In regression 4 , the policy interest rate obtains a negative coefficient that is significant at $1 \%$, while its interaction with Borrower E/A obtains a positive coefficient that is significant at $5 \%$. This suggests that a lower policy interest rate is associated with a high loan spread, especially for undercapitalized borrowers.

In regression 5, the collateral dummy is negatively and significantly related to the policy interest rate, indicating that a lower policy interest rate increases loan collateralization. In regression 6 , collateralization is positively and significantly related to the policy interest rate, while it is negatively and significantly related to the interaction of the policy rate and Borrower E/A. Hence, a lower policy interest rate is estimated to increase collateralization relatively little for highly leveraged borrowers.

Finally, regressions 7 and 8 relate the policy interest rate to the covenant dummy. Regression 7 shows a positive, insignificant coefficient for the policy interest rate; regression 8 shows a negative, significant coefficient for this variable, while its interaction with Borrower E/A is negative and insignificant. Hence, there is some evidence that a lower policy interest rate increases covenant use, which by itself should reduce the riskiness of crossborder syndicated loans.

Overall, we find evidence that a lower policy interest rate increases loan maturity which by itself is likely to increase credit risk. At the same time, a lower policy rate gives rise to a higher loan spread and more collateralization, which may reduce credit risk. Borrower heterogeneity, however, is important: a lower policy interest rate increases the loan spread especially for under-capitalized borrowers, while it increases collateralization especially for better capitalized borrowers.

\section{Foreign banks and the transmission of monetary policy}


Our evidence so far indicates that changes in lender-country policy interest rates are transmitted to borrower countries as shocks to credit supply volumes and other credit terms. As business cycles internationally do not necessarily move in tandem, these credit supply shocks may serve to destabilize rather than stabilize borrower firms and economies. The potential for such credit supply shocks to be destabilizing is larger, the larger is the sensitivity of lender banks' credit supply to lender-country policy interest rates.

Policy makers in borrower countries generally have an interest in mitigating the transmission of lender-country monetary policy to their economies. Hence, it is useful to know how key economic institutions and financial policies affect monetary policy transmission through the provision of cross-border loans.

Of particular interest is the foreign ownership of local banks, as credit provided by local foreign banks in principle can substitute for cross-border loan provision. ${ }^{6}$ A priori, the impact of foreign banking presence on the sensitivity of cross-border loan provision to lender-country monetary policy is ambiguous. On the one hand, a local foreign bank presence makes it easier for international banks to gain experience with local borrowers and to be more informed about them. This could increase the value of local credit relationships to international banks, providing lender banks with an incentive to make cross-border loan provision less sensitive to lender-country monetary policy rates (de Haas and van Horen, 2013). On the other hand, multinational banks may be inclined to reallocate capital from foreign subsidiaries to headquarters when monetary conditions tighten (Cetorelli and Goldberg, 2012), rendering the provision of international syndicated loans more sensitive to lender-country policy interest rates. This section provides evidence on how foreign bank

\footnotetext{
${ }^{6}$ Overall foreign bank presence and international syndicated loan provision are complements as indicated by a positive correlation between the foreign-owned banks and loan volume variables of 0.17 which is significant at $1 \%$.
} 
presence affects the transmission of lender-country monetary policy to loan volume and other loan credit terms in the syndicated loan market.

To start, Table 5 provides evidence on how foreign bank presence affects the relationship between the volume of loans to non-financial firms and lender-country monetary policy. In Panels A and B of the table, foreign bank presence is represented by the ForeignOwned Banks, borrower and FDI variables, respectively. The loan volume regression 1 of Panel A, in particular, includes the IR variable and an interaction of this variable with the foreign-owned banks variable. These variables receive negative and positive coefficients, respectively, that are both significant at $1 \%$. This suggests that foreign bank presence mitigates the negative impact of higher lender-country policy interest rate on cross-border loan volume.

Next, we consider whether this result is robust to the inclusion of a range of other policy and institutional variables. Regressions $2-4$, in particular, contain interest rate interactions with lender-country bank supervisory and regulatory indices (supervisory power, capital stringency, and restrictions), yielding a negative and significant coefficient for the interaction of IR with the Overall Capital Stringency, lender variable in regression 3. Stringent capitalization policies in the lender country thus are estimated to amplify the impact of policy interest rates on credit supply, potentially because such policies make banks stronger so that they have the capacity to increase their loan supply more in case policy interest rates decline. Regressions 5-7 include interactions with analogous supervisory and regulatory indices for the borrower country that are all estimated with insignificant coefficients. Regressions 8 and 9 include interactions of the IR variable with the ER flexibility and Credit Constraint (in) variables, respectively, that also receive insignificant coefficients. The IR variable itself is estimated with negative and significant coefficients in regressions $1,4,6,8$, and 9, while its interactions with the foreign-owned banks variable 
obtain positive and significant coefficients throughout the panel. Foreign bank presence thus is shown to mitigate the transmission of lender-country policy interest rates to loan volume in a range of regressions where we control for other institutional and policy variables that could affect monetary policy transmission.

The regressions of Panel B include the FDI variable as a proxy for foreign bank presence and are otherwise analogous to those of Panel A. In regression 1, the IR variable obtains a negative and significant coefficient, while the FDI variable obtains a positive and significant coefficient. The latter result suggests that foreign bank presence and cross border loan provision complement each other. In this regression the interaction of IR and FDI obtains a positive coefficient that is insignificant. In regressions 3, the Overall Capital Stringency, lender variable enters with a negative and significant coefficient similarly to regression 3 in Panel A. In regression 4, the Overall Restrictions on Banking Activities, lender variable obtains a positive and significant coefficient. Thus banks that face more restrictions on their activities are found to increase cross-border lending relatively less following a reduction of policy interest rates. This may reflect that banks that are subject to more restrictions have less leeway to adjust the volumes and riskiness of all their overall activities, making cross-border lending less responsive to interest rate changes. In regression 8 , the interaction variable of the policy interest rate with a dummy variable indicating that the borrower country has a flexible exchange rate regime obtains a negative and significant coefficient. Hence, a lower policy interest rate increases loan supply relatively more to borrowers located in countries with flexible exchange rate regimes. Potentially, this reflects that a lower lender-country policy rate causes an appreciation of borrower-country's currency vis-à-vis the lender-country's currency, which increases the valuation of the borrower firm in lender-country currency and hence its capacity to borrow internationally. This provides additional support for the results in Bruno and Shin (2015b), who find that local currency 
appreciation is a driver of banking capital inflows. In regressions 2-9, the IR, IR * FDI, and FDI variables receive negative, positive and positive coefficients, respectively, in those regressions where they are significant. The results of both panels of Table 5 thus imply an attenuating impact of foreign bank presence on the sensitivity of cross-border loans to lendercountry policy interest rates.

Next, we recognize that foreign bank could possibly be related to the borrower country's overall economic and financial development (Claessens and van Horen, 2014). In panel $\mathrm{C}$ of Table 7 , we investigate whether the mitigating role of foreign bank presence in the transmission of monetary policy is robust to controlling for various proxies of economic and financial development. Regressions 1-5 include the foreign ownership variable to proxy for foreign bank presence, while regressions 6-10 include the FDI variable. In regressions 1, 3, 4 and 5 the interactions between IR and alternatively GDP per capita, Domestic credit, Market cap and Turnover ratio obtain positive and significant coefficients, providing some evidence that borrower-country economic and financial development mitigates the transmission of monetary policy via the syndicated loan market. In regressions 1-5, IR and its interaction with Foreign-owned banks, borrower, obtain negative and positive significant coefficients, respectively, that are significant. This suggest that the mitigating role of foreign bank presence in the monetary transmission process does not simply reflect borrower-country economic and financial development. In regressions 6 to 10, the interactions of IR and FDI have positive and insignificant coefficients similar to regression 1 of Panel B.

Foreign bank presence may matter for the transmission of monetary policy through the cross-border loan market either because it is correlated with the lender bank's own experience and local presence in the borrower country, or alternatively because of the role played by other foreign banks in the borrower country, for instance through improving the quantity and quality of information that is available on potential new borrowers. 
In regression 1 of Table 6, we examine whether there remains an influence of foreignowned banks on the monetary transmission process after we control for the experience that a lender bank itself has in providing loans in the borrower country. Specifically, we include the experience variable and its interaction with IR in regression 1 of Panel A of Table 5, yielding positive and significant coefficients for these two variables. This implies that a bank's own experience in the borrower country mitigates the monetary transmission process, perhaps because a bank's prior experience in a borrower country provides it with incentives to shield its existing customers from changes in the lender-country policy interest rate. In this regression, the IR * Foreign-Owned Banks, borrower variable obtains a positive coefficient that is significant at $10 \%$, which suggests that foreign-owned banks affect the monetary transmission process independently from the bank's own lending experience in the borrower country. In the analogous regression 2 , the IR * FDI variable similarly is estimated with a positive and significant coefficient, while the IR * Experience variable is estimated with a negative and insignificant coefficient.

Regression 4 examines the role of foreign-owned banks in the monetary transmission process while controlling for whether the lender bank itself has had a subsidiary in the borrower country. In this regression, the subsidiary variable and its interaction with IR receive positive significant and positive insignificant coefficients, respectively, while the IR * Foreign-Owned Banks, borrower variable is estimated with a positive and significant coefficient. These results suggest that foreign bank presence in general rather than a bank's own local presence in a borrower country weakens the transmission of lender-country monetary policy. Regression 5 in addition includes a triple interaction of the IR, Subsidiaries, and Foreign-Owned Banks, borrower variables, which is insignificant. Regression 7 includes the FDI variable and is otherwise analogous to regression 5. In this regression, the estimated coefficient for the double interaction IR * FDI is 0.534 , while the estimated coefficient for 
the triple interaction IR * Subsidiaries * FDI is -0.409 , with both of these coefficients being significant at 5\%. These estimated coefficients imply that the mitigating impact of banking FDI on monetary policy is reduced but not eliminated when we control for a bank's own subsidiary presence in a borrower country.

So far, we have considered loan volume as aggregated at the level of the parent bank even if this parent bank has foreign subsidiaries. For these foreign subsidiaries, however, the relevant monetary policy rate may be the policy rate of their respective host countries rather than the policy rate of the country where the parent resides. To allow for this, we next disaggregate a multinational bank's cross-border loans into lending stemming from the parent country, and lending coming from any of the foreign countries where the multinational bank has at least one foreign subsidiary. Lending coming from the various countries where a multinational bank operates are then treated as separate observations and related to the monetary policy rate of a lending unit's country of location. Regressions 8 and 9 of Table 6 report results analogous to regressions 1 of the two panels of Table 5. In these regressions, the IR variable obtains negative and significant coefficient, while the interactions IR * Foreign-Owned Banks, borrower and IR * FDI included in regressions 8 and 9, respectively, obtain positive and significant coefficients. Thus our finding of a mitigating impact of foreign bank presence on monetary policy transmission is robust to disaggregating a multinational bank's lending to the respective host countries where its constituent lending units reside.

Following a higher lender-country policy interest rate, an international bank that has a subsidiary in the borrowing country has the option to substitute local funding for parentcountry funding that has become more expensive. This could explain why foreign bank presence reduces the sensitivity of syndicated loan supply to the lender-country policy interest rate. Next, we consider the sensitivity of syndicated loan supply to the lender-country policy interest rate while controlling for the effect of the borrower country policy interest 
rate. Specifically, regression 1 of Table 7 relates loan volume to the lender-country policy rate and an interaction of the policy interest rates in lender and borrower countries. The interaction variable receives a negative coefficient, consistent with a heightened sensitivity of loan volume to the lender-country policy interest rate in borrower countries with high policy interest rates, but the coefficient is insignificant. Regression 2 adds the IR * Foreign-Owned Banks, borrower variable which receives a positive and significant coefficient, while the IR * IR (Borrower) variable receives a negative and significant coefficient. These results suggest that higher foreign bank presence and borrower country interest rates reduce and increase the transmission to loan volume of lender-country monetary policy, respectively. Regression 3 in addition includes the triple interaction variable IR * IR (Borrower) * Foreign-Owned Banks, borrower, which is estimated with an insignificant coefficient. Regressions 4 and 5 include the FDI variable as a proxy for foreign bank presence and otherwise are analogous to regressions 2 and 3. In regression 5, the triple interaction variable IR * IR (Borrower) * FDI receives a negative and significant coefficient, indicating that foreign bank presence mitigates the sensitivity of the loan volume to the lender-country policy interest rate less if the borrower-country policy rate is relatively high. This likely reflects that a multinational's borrower-country and lender-country funding are less substitutable if the borrower-country policy interest rate is relatively high (as in that instance lender-country funding may be much cheaper).

Lending provided through an international bank's borrower-country subsidiaries strictly speaking is not cross-border lending. Next, we consider how an international bank's loan supply net of the loan supply through local subsidiaries is affected by lender-country policy interest rates. Specifically, regression 6 relates loan volume net of lending by borrower-country subsidiaries to the lender country policy rate and its interaction with the foreign-owned banks variable. The interaction variable is estimated with a positive and 
significant coefficient analogously to regression 1 in Panel A of Table 5, implying an

attenuating influence of foreign bank presence on the sensitivity of truly cross-border loans to the lender-country monetary policy rate. Regression 7 includes an interaction of the lendercountry policy interest rate with FDI in a similar regression yielding an insignificant coefficient for this interaction variable comparable to regression 1 in Panel B of Table 5.

Overall, our results suggest that foreign bank presence renders the cross-border loan volume of international banks to non-financial borrowers less sensitive to lender-country policy interest rates. There is some evidence that the attenuating effect of overall banking FDI in a country on loan volume is reduced but not eliminated by a multinational bank itself having a subsidiary in the borrower country, which suggests that the impact of banking FDI on the transmission of lender-country monetary policy partly results from other banks having subsidiaries in the borrower country and partly from an international bank having a subsidiary in the borrower country itself. Furthermore, there is evidence that the mitigating impact of banking FDI on the international transmission of monetary policy to loan volume is weaker if the borrower-country policy interest rate is higher, since this is likely to reduce the ability of a multinational bank to substitute borrower-country funding for lender-country funding. ${ }^{7}$

\section{Conclusion}

\footnotetext{
${ }^{7}$ We also explored how foreign bank presence affects the transmission of lender-country monetary policy to non-volume credit terms. These results are unreported, but can be summarized as follows. A regression relating loan maturity to the IR variable and an interaction of this variable with the FDI variable yields negative and positive coefficients, respectively, that are both significant. This suggests that foreign banking presence mitigates the tendency of lower policy interest rates to engender longer loan maturity. In addition, we find that foreign bank presence as measured by FDI strengthens the tendency for lower policy interest rates to lead to greater collateralization and covenant use.
} 
This paper investigates the role of foreign banks in the international transmission of monetary policy changes to foreign countries through the market for cross-border syndicated loans. Our data set includes lenders in 50 countries, and borrowers in 124 countries. The inclusion of multiple lender and borrower countries has two main advantages. First, we can include borrower*time fixed effects to control for potentially time-varying loan demand at the individual borrower level. Second, the inclusion of multiple borrower countries enables us to investigate the impact of varying borrower-country policies and institutions on the transmission of lender-country monetary policy.

We find that an expansion of monetary policy through a lower policy interest rate increases cross-border credit supply especially to weaker firms as measured by the equity-toassets ratio in line with earlier research.

Our main result is that foreign ownership of banking in the borrower country reduces the tendency for loan volume to increase following a lender-country policy interest rate reduction. This finding is robust to controlling for the level of economic and financial development in the borrower country, and for a range of financial policies and institutions in the borrower and lender countries, including the strength of bank regulation and supervision, exchange rate flexibility and restrictions on capital flows.

A local presence of a multinational bank in a borrower country is found to reduce, but not eliminate, the attenuating effect of overall banking FDI on the transmission of monetary policy to loan volume. This suggests that the impact of banking FDI on the transmission of lender-country monetary policy partly results from other banks having subsidiaries in the borrower country as well as from the international bank having a subsidiary in the borrower country itself. Moreover, the mitigating impact of banking FDI on the international transmission of monetary policy to loan volume is weaker, if the borrower-country policy 
interest rate is higher. This potentially reflects that a multinational's local and international funding are less substitutable, if the borrower-country interest rate is higher.

Our finding that banking FDI in borrower countries could stabilize the international supply of cross-border loans importantly qualifies the picture of international banks as sources of credit instability in borrower countries that transmit international monetary policy changes in the form of international credit supply shocks. Our evidence also suggests that countries that currently restrict the foreign ownership of local banks can potentially obtain a more stable supply of cross-border credit in the face of international monetary policy shocks if they allow additional foreign bank entry. 


\section{References}

Aiyar, S. (2012). From financial crisis to great recession: The role of globalized banks. American Economic Review, 102(3):225-230.

Altunbas, Y., Gambacorta, L., and Marques-Ibanez, D. (2010). Bank risk and monetary policy. Journal of Financial Stability, 6(3):121-129.

Barth, J. R., Caprio Jr, G., and Levine, R. (2013). Bank regulation and supervision in 180 countries from 1999 to 2011. Journal of Financial Economic Policy, 5(2):111-219.

Bertay, A., A. Demirguc-Kunt, and H. Huizinga (2015), Bank ownership and credit over the business cycle: Is lending by state banks less procyclical?, Journal of Banking and Finance 50, 326-339.

Bruno, V., and Shin, H. S. (2015a). Capital flows and the risk-taking channel of monetary policy. Journal of Monetary Economics, 71:119-132.

Bruno, V., and Shin, H. S. (2015b). Cross-border banking and global liquidity. Review of Economic Studies, 82(2):535-564.

Cetorelli, N., and Goldberg, L. S. (2011). Global banks and international shock transmission: Evidence from the crisis. IMF Economic Review, 59(1):41-76.

Cetorelli, N. and Goldberg, L. S. (2012a). Banking globalization and monetary transmission. Journal of Finance, 67(5):1811-1843.

Cetorelli, N., and Goldberg, L. S. (2012b). Liquidity management of US global banks: Internal capital markets in the great recession. Journal of International Economics, 88(2):299-311.

Chava, S., and Roberts, M. R. (2008). How does financing impact investment? The role of debt covenants. Journal of Finance, 63(5):2085-2121.

Claessens, S. and Van Horen, N. (2012). Being a foreigner among domestic banks: Asset or liability? Journal of Banking and Finance, 36(5):1276-1290. 
Claessens, S., and van Horen, N. (2014), Foreign banks: Trends and impact. Journal of Money, Credit and Banking, 46: 295-326.

Claessens, S., and van Horen, N. (2015). The Impact of the Global Financial Crisis on Banking Globalization. IMF Economic Review, 63(4):868-918.

de Haas, R., and van Horen, N. (2012). International shock transmission after the Lehman Brothers collapse: Evidence from syndicated lending. American Economic Review Papers \& Proceedings, 102(3):231-237.

de Haas, R., and van Horen, N. (2013). Running for the exit? International bank lending during a financial crisis. Review of Financial Studies, 26(1):244-285.

De Haas, R. and Van Lelyveld, I. (2006). Foreign banks and credit stability in Central and Eastern Europe. A panel data analysis. Journal of Banking and Finance, 30(7):19271952.

den Haan, W. J., Sumner, S. W., and Yamashiro, G. M. (2007). Bank loan portfolios and the monetary transmission mechanism. Journal of Monetary Economics, 54(3):904-924.

Fernández, A., Klein, M. W., Rebucci, A., Schindler, M., and Uribe, M. (2015). Capital control measures: A new dataset. NBER Working Papers 20970, National Bureau of Economic Research, Cambridge, MA.

Ferreira, M. A., and Matos, P. (2012). Universal banks and corporate control: Evidence from the global syndicated loan market. Review of Financial Studies, 25(9):27032744.

Fischer, S. (2014). The Federal Reserve and the global economy. Speech by Vice Chairman of the Board of Governors of the Federal Reserve System delivered as the Per Jacobson Foundation Lecture 2014 Annual Meetings of the International Monetary Fund and the World Bank Group Washington D.C. 
Gambacorta, L. (2005). Inside the bank lending channel. European Economic Review, 49(7):1737-1759.

Gambacorta, L., and Marques-Ibanez, D. (2011). The bank lending channel: lessons from the crisis. Economic Policy, 26(66):135-182.

Giannetti, M., and Laeven, L. (2012a). The flight home effect: Evidence from the syndicated loan market during financial crises. Journal of Financial Economics, 104(1):2343.

Giannetti, M., and Laeven, L. (2012b). Flight home, flight abroad, and international credit cycles. American Economic Review, 102(3):219-224.

Ilzetzki, E., Reinhart, C. M., and Rogoff, K. S. (2011). The country chronologies and background material to exchange rate arrangements into the 21st century: Will the anchor currency hold. Mimeo.

Ioannidou, V., Ongena, S., and Peydró, J.-L. (2015). Monetary policy, risk-taking, and pricing: Evidence from a quasi-natural experiment. Review of Finance, 19(1):95-144.

Ivashina, V., Scharfstein, D. S., and Stein, J. C. (2015). Dollar funding and the lending behavior of global banks. Quarterly Journal of Economics, 1241:1281.

Jiménez, G., Ongena, S., Peydró, J.-L., and Saurina, J. (2012a). Credit supply and monetary policy: Identifying the bank balance-sheet channel with loan applications. American Economic Review, 102(5):2301-2326.

Jiménez, G., Ongena, S., Peydró, J.-L., and Saurina, J. (2014a). Hazardous times for monetary policy: What do twenty-three million bank loans say about the effects of monetary policy on credit risk-taking? Econometrica, 82(2):463-505.

Kim, S. (2001). International transmission of US monetary policy shocks: Evidence from VAR's. Journal of Monetary Economics, 48(2):339-372. 
Miranda-Agrippino, S., and Rey, H. (2015). World asset markets and the global financial cycle. NBER Working Papers 21722, National Bureau of Economic Research, Cambridge, MA.

Morais, B., Peydró, J.-L., and Ruiz, C. (2015). The international bank lending channel of monetary policy rates and quantitative easing: credit supply, reach-for-yield, and real effects. World Bank Policy Research Working Paper, 7216.

Ongena, S., Peydró, J.-L., and Van Horen, N. (2015). Shocks abroad, pain at home? Bank-firm-level evidence on the international transmission of financial shocks. IMF Economic Review, 63(4):698-750.

Ongena, S., Popov, A., and Udell, G. F. (2013). "When the cat's away the mice will play": Does regulation at home affect bank risk-taking abroad? Journal of Financial Economics, 108(3):727-750.

Peek, J., and Rosengren, E. S. (1997). The international transmission of financial shocks: The case of Japan. American Economic Review, 87(4):495.

Rajan, R. (2014). Competitive monetary easing: Is it yesterday once more? Speech at the Brookings Institution, April 10, 2014.

Rey, H. (2013). Dilemma not trilemma: The global financial cycle and monetary olicy independence. Paper presented at "Global Dimensions of Unconventional Monetary Policy," Jackson Hole, Federal Reserve Bank, August 22-24.

Rey, H. (2016). International channels of transmission of monetary policy and the Mundellian trilemma. IMF Economic Review, 64(1):6-35.

Temesvary, J., Ongena, S., and Owen, A. L. (2015). A global lending channel unplugged? Does US monetary policy affect cross-border and affiliate lending by global US banks? MPRA Paper, 65913, University Library of Munich, Germany. 
Appendix

Table A1: List of lender countries

\begin{tabular}{|c|c|c|c|c|c|}
\hline Country & Number of lenders & Number of loans & Country & Number of lenders & Number of loans \\
\hline Austria & 21 & 815 & Korea (South) & 24 & 734 \\
\hline Belgium & 8 & 2,143 & Luxembourg & 3 & 122 \\
\hline Brazil & 3 & 121 & Malaysia & 8 & 392 \\
\hline Canada & 16 & 8,034 & Mauritius & 2 & 13 \\
\hline Chile & 3 & 19 & Mexico & 1 & 2 \\
\hline China & 25 & 1,774 & Morocco & 3 & 21 \\
\hline Colombia & 1 & 6 & Netherlands & 15 & 3,165 \\
\hline Cyprus & 2 & 7 & Norway & 6 & 1,446 \\
\hline Denmark & 8 & 598 & Philippines & 13 & 74 \\
\hline Egypt & 4 & 18 & Portugal & 6 & 386 \\
\hline Finland & 4 & 25 & Qatar & 3 & 38 \\
\hline France & 20 & 9,670 & Romania & 1 & 5 \\
\hline Germany & 36 & 9,907 & Russia & 4 & 16 \\
\hline Greece & 4 & 47 & Saudi Arabia & 4 & 22 \\
\hline Hong Kong & 22 & 812 & Singapore & 16 & 2,417 \\
\hline Hungary & 1 & 2 & Slovenia & 1 & 2 \\
\hline Iceland & 2 & 14 & South Africa & 6 & 173 \\
\hline India & 20 & 506 & Spain & 19 & 2,864 \\
\hline Indonesia & 5 & 106 & Sri Lanka & 1 & 2 \\
\hline Iran & 1 & 2 & Sweden & 6 & 559 \\
\hline Ireland & 5 & 564 & Switzerland & 19 & 3,754 \\
\hline Israel & 3 & 423 & Thailand & 9 & 231 \\
\hline Italy & 19 & 3,712 & Turkey & 3 & 26 \\
\hline Japan & 81 & 16,967 & USA & 103 & 6,550 \\
\hline \multirow[t]{2}{*}{ Jordan } & 1 & 61 & United Kingdom & 26 & 13,856 \\
\hline & & & Total & 617 & 93,223 \\
\hline
\end{tabular}


Table A2: List of borrower countries

\begin{tabular}{|c|c|c|c|c|c|}
\hline Country & Number of borrowers & Number of loans & Country & Number of borrowers & Number of loans \\
\hline Algeria & 3 & 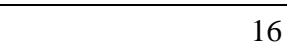 & Denmark & 23 & 217 \\
\hline Angola & 2 & 60 & Ecuador & 2 & 4 \\
\hline Argentina & 22 & 158 & Egypt & 5 & 88 \\
\hline Australia & 483 & 4,088 & El Salvador & 1 & 3 \\
\hline Austria & 16 & 168 & Estonia & 5 & 23 \\
\hline Azerbaijan & 3 & 28 & Finland & 58 & 574 \\
\hline Bahamas & 9 & 38 & France & 178 & 2,291 \\
\hline Bahrain & 5 & 42 & Gabon & 2 & 16 \\
\hline Bangladesh & 8 & 60 & Georgia & 1 & 2 \\
\hline Barbados & 2 & 22 & Germany & 139 & 1,435 \\
\hline Belarus & 1 & 7 & Ghana & 5 & 172 \\
\hline Belgium & 53 & 466 & Gibraltar & 1 & 3 \\
\hline Bermuda & 59 & 837 & Greece & 41 & 198 \\
\hline Bolivia & 1 & 12 & Guinea & 1 & 6 \\
\hline Botswana & 1 & 4 & Hong Kong & 518 & 5,958 \\
\hline Brazil & 71 & 681 & Hungary & 14 & 160 \\
\hline British Virgin Islands & 26 & 349 & Iceland & 8 & 105 \\
\hline Brunei & 3 & 23 & India & 194 & 2,024 \\
\hline Bulgaria & 6 & 16 & Indonesia & 291 & 2,671 \\
\hline Cambodia & 2 & 9 & Iran & 5 & 36 \\
\hline Cameroon & 2 & 10 & Ireland & 37 & 237 \\
\hline Canada & 147 & 1,105 & Israel & 12 & 110 \\
\hline Cayman Islands & 39 & 174 & Italy & 104 & 794 \\
\hline Chile & 33 & 328 & Ivory Coast & 4 & 11 \\
\hline China & 407 & 2,865 & Jamaica & 1 & 2 \\
\hline Colombia & 17 & 85 & Japan & 79 & 743 \\
\hline Congo & 1 & 2 & Jordan & 3 & 6 \\
\hline Costa Rica & 1 & 7 & Kazakhstan & 14 & 91 \\
\hline Croatia & 17 & 108 & Kenya & 4 & 13 \\
\hline Cyprus & 15 & 109 & Korea (South) & 226 & 2,480 \\
\hline Czech Republic & 19 & 179 & Kosovo & 1 & 3 \\
\hline Country & Number of borrowers & Number of loans & Country & Number of borrowers & Number of loans \\
\hline
\end{tabular}




\begin{tabular}{|c|c|c|c|c|c|}
\hline Kuwait & 7 & 38 & Qatar & 19 & 239 \\
\hline Laos & 5 & 32 & Romania & 31 & 121 \\
\hline Latvia & 3 & 8 & Russia & 84 & 847 \\
\hline Liberia & 6 & 35 & Rwanda & 1 & 2 \\
\hline Lithuania & 3 & 8 & Saudi Arabia & 13 & 94 \\
\hline Luxembourg & 31 & 398 & Serbia & 1 & 6 \\
\hline Macau & 14 & 183 & Singapore & 251 & 2,045 \\
\hline Malawi & 1 & 3 & Slovakia & 16 & 91 \\
\hline Malaysia & 141 & 1,043 & Slovenia & 3 & 19 \\
\hline Mali & 1 & 4 & South Africa & 28 & 413 \\
\hline Malta & 3 & 21 & Spain & 297 & 2,926 \\
\hline Mauritius & 9 & 85 & Sri Lanka & 2 & 9 \\
\hline Mexico & 84 & 973 & Sweden & 82 & 1,076 \\
\hline Moldova & 1 & 9 & Switzerland & 60 & 1,353 \\
\hline Monaco & 2 & 5 & Taiwan & 196 & 1,274 \\
\hline Mongolia & 2 & 4 & Tanzania & 3 & 23 \\
\hline Morocco & 5 & 30 & Thailand & 167 & 1,350 \\
\hline Netherlands & 191 & 2,149 & Trinidad and Tobago & 2 & 11 \\
\hline Netherlands Antilles & 1 & 5 & Tunisia & 5 & 33 \\
\hline New Zealand & 49 & 333 & Turkey & 37 & 288 \\
\hline Nicaragua & 1 & 4 & Turkmenistan & 3 & 7 \\
\hline Nigeria & 6 & 27 & USA & 2,996 & 36,162 \\
\hline Norway & 82 & 632 & Ukraine & 19 & 103 \\
\hline Oman & 9 & 76 & United Arab Emirates & 42 & 384 \\
\hline Pakistan & 25 & 149 & United Kingdom & 349 & 3,365 \\
\hline Panama & 33 & 158 & Uruguay & 1 & 2 \\
\hline Papua New Guinea & 8 & 92 & Uzbekistan & 4 & 22 \\
\hline Peru & 17 & 119 & Venezuela & 6 & 46 \\
\hline Philippines & 63 & 904 & Vietnam & 42 & 240 \\
\hline Poland & 31 & 298 & Yemen & 1 & 16 \\
\hline \multirow[t]{2}{*}{ Portugal } & 30 & 289 & Zambia & 3 & 10 \\
\hline & & & Total & 9,079 & 93,223 \\
\hline
\end{tabular}


Table A3: Variable definitions

\begin{tabular}{|c|c|c|}
\hline Variable & Description & Source \\
\hline Volume & $\begin{array}{l}\text { Natural logarithm of the dollar amount of a banks' share } \\
\text { in a syndicated loan, aggregated at the borrower-lender- } \\
\text { time level }\end{array}$ & Dealscan \\
\hline Maturity & Maturity of a facility in months & Dealscan \\
\hline Spread & $\begin{array}{l}\text { Loan spread over the reference rate in basis points for } \\
\text { drawn credit of a facility }\end{array}$ & Dealscan \\
\hline Collateral & $\begin{array}{l}\text { Dummy variable indicating that a loan is collateralized. } \\
\text { Takes the value of one if Dealscan indicates "Yes" in } \\
\text { the "Secured" field, } 0 \text { in case of a "No" answer, and } \\
\text { missing otherwise }\end{array}$ & Dealscan \\
\hline Covenant & $\begin{array}{l}\text { Dummy variable indicating that there is a net worth or } \\
\text { financial ratio covenant in the loan contract }\end{array}$ & Dealscan \\
\hline IR & $\begin{array}{l}\text { The central bank policy rate or the discount rate in the } \\
\text { lender's country }\end{array}$ & IFS \\
\hline IR (Borrower) & $\begin{array}{l}\text { The central bank policy rate or the discount rate in the } \\
\text { borrower's country }\end{array}$ & IFS \\
\hline Taylor residual & $\begin{array}{l}\text { Error from a regression of the monetary policy rate (IR) } \\
\text { on the real GDP growth rate and the inflation rate (CPI) } \\
\text { separately for each lender country }\end{array}$ & IFS \\
\hline QE & $\begin{array}{l}\text { Dummy variable indicating that a quantitative easing } \\
\text { program was in place in the following economies and } \\
\text { periods: U.S.: 2009M1 to 2015M12; Eurozone: } \\
\text { 20015M3 to 2015M12;U.K.: 2009M3 to 2015M12; and } \\
\text { Japan: 2001M3 to 2006M3 and 2013M4 to 2015M12 }\end{array}$ & \\
\hline Borrower E/A & $\begin{array}{l}\text { Book value of common equity to book value of total } \\
\text { assets, lagged by one year }\end{array}$ & Worldscope \\
\hline $\begin{array}{l}\text { Foreign-Owned Banks, } \\
\text { borrower }\end{array}$ & $\begin{array}{l}\text { Fraction of the banking system's assets in the borrower's } \\
\text { country that is foreign owned, in percentage points }\end{array}$ & $\begin{array}{l}\text { World Bank Regulation } \\
\text { and Supervision Survey } \\
\text { (Barth et al. (2013)) }\end{array}$ \\
\hline FDI & $\begin{array}{l}\text { Number of subsidiaries in the country of the borrower } \\
\text { owned by banks in the lender's country }\end{array}$ & $\begin{array}{l}\text { Claessens and van } \\
\text { Horen }(2015)\end{array}$ \\
\hline Experience & $\begin{array}{l}\text { Natural logarithm of } 1+\text { the number of loans extended } \\
\text { by the lender in the country of the borrower in the three } \\
\text { years prior to the loan }\end{array}$ & Dealscan \\
\hline Subsidiaries & $\begin{array}{l}\text { Dummy variable that equals one if the lender company } \\
\text { has at least one subsidiary in the borrower country } \\
\text { during the sample period and zero otherwise }\end{array}$ & Dealscan \\
\hline Official Supervisory & Index of the power of the supervisory authorities in the & World Bank Regulation \\
\hline Power, borrower & $\begin{array}{l}\text { borrower's country to take specific actions to prevent } \\
\text { and correct problems in banks, with higher values } \\
\text { indicating greater power }\end{array}$ & $\begin{array}{l}\text { and Supervision Survey } \\
\text { (Barth et al. (2013)) }\end{array}$ \\
\hline Overall Capital & Index measuring the stringency in determining & World Bank Regulation \\
\hline Stringency, borrower & $\begin{array}{l}\text { minimum capital adequacy in the borrower's country, } \\
\text { with higher values indicating greater stringency }\end{array}$ & $\begin{array}{l}\text { and Supervision Survey } \\
\text { (Barth et al. (2013)) }\end{array}$ \\
\hline $\begin{array}{l}\text { Overall Restrictions on } \\
\text { Banking Activities, } \\
\text { borrower }\end{array}$ & $\begin{array}{l}\text { Index of the extent to which banks in the borrower's } \\
\text { country can engage in securities, insurance and real } \\
\text { estate activities, with higher values indicating more } \\
\text { restrictions }\end{array}$ & $\begin{array}{l}\text { World Bank Regulation } \\
\text { and Supervision Survey } \\
\text { (Barth et al. (2013)) }\end{array}$ \\
\hline $\begin{array}{l}\text { Official Supervisory } \\
\text { Power, lender }\end{array}$ & $\begin{array}{l}\text { Index of the power of the supervisory authorities in the } \\
\text { lender's country to take specific actions to prevent and } \\
\text { correct problems in banks, with higher values indicating } \\
\text { greater power }\end{array}$ & $\begin{array}{l}\text { World Bank Regulation } \\
\text { and Supervision Survey } \\
\text { (Barth et al. (2013)) }\end{array}$ \\
\hline $\begin{array}{l}\text { Overall Capital } \\
\text { Stringency, lender }\end{array}$ & $\begin{array}{l}\text { Index measuring the stringency in determining } \\
\text { minimum capital adequacy in the lender's country, with } \\
\text { higher values indicating greater stringency }\end{array}$ & $\begin{array}{l}\text { World Bank Regulation } \\
\text { and Supervision Survey } \\
\text { (Barth et al. (2013)) }\end{array}$ \\
\hline
\end{tabular}


Overall Restrictions on Banking Activities, lender

ER flexibility

Credit Constraints (in)

GDP per capita

Credit

Domestic credit

Market cap

Turnover ratio

CPI

GDP growth
Index of the extent to which banks in the lender's country can engage in securities, insurance and real estate activities, with higher values indicating more restrictions

Dummy variable indicating that the borrower's country has a flexible exchange rate regime. It takes the value of one if a country's exchange rate regime falls in one of the following categories: pre-announced crawling band that is wider than or equal to $+/-2 \%$; de facto crawling band that is narrower than or equal to $+/-5 \%$; moving band that is narrower than or equal to $+/-2 \%$ (i.e., allows for both appreciation and depreciation over time); managed floating; and freely floating Dummy variable indicating the presence of restrictions on the inflow of commercial credit in the borrower's country

GDP per capita in constant 2005 US dollars

World Bank Regulation and Supervision Survey (Barth et al. (2013))

Ilzetzky, Reinhart and Rogoff (2011)

Domestic credit to the private sector by banks as a percentage of GDP

Domestic credit provided by the financial sector as a percentage of GDP

Market capitalization of listed companies as a percentage of GDP

Total value of shares traded during the period as a percentage of the average market capitalization for the period in percentage points

Annual percentage change of the consumer price index in the lender's country

Annual percentage change of real GDP in the lender's country
Fernández, Klein,

Rebucci, Schindler and Uribe (2015)

WDI

WDI

WDI

WDI

WDI

IFS

IFS 
Figure 1: Total cross-border syndicated lending

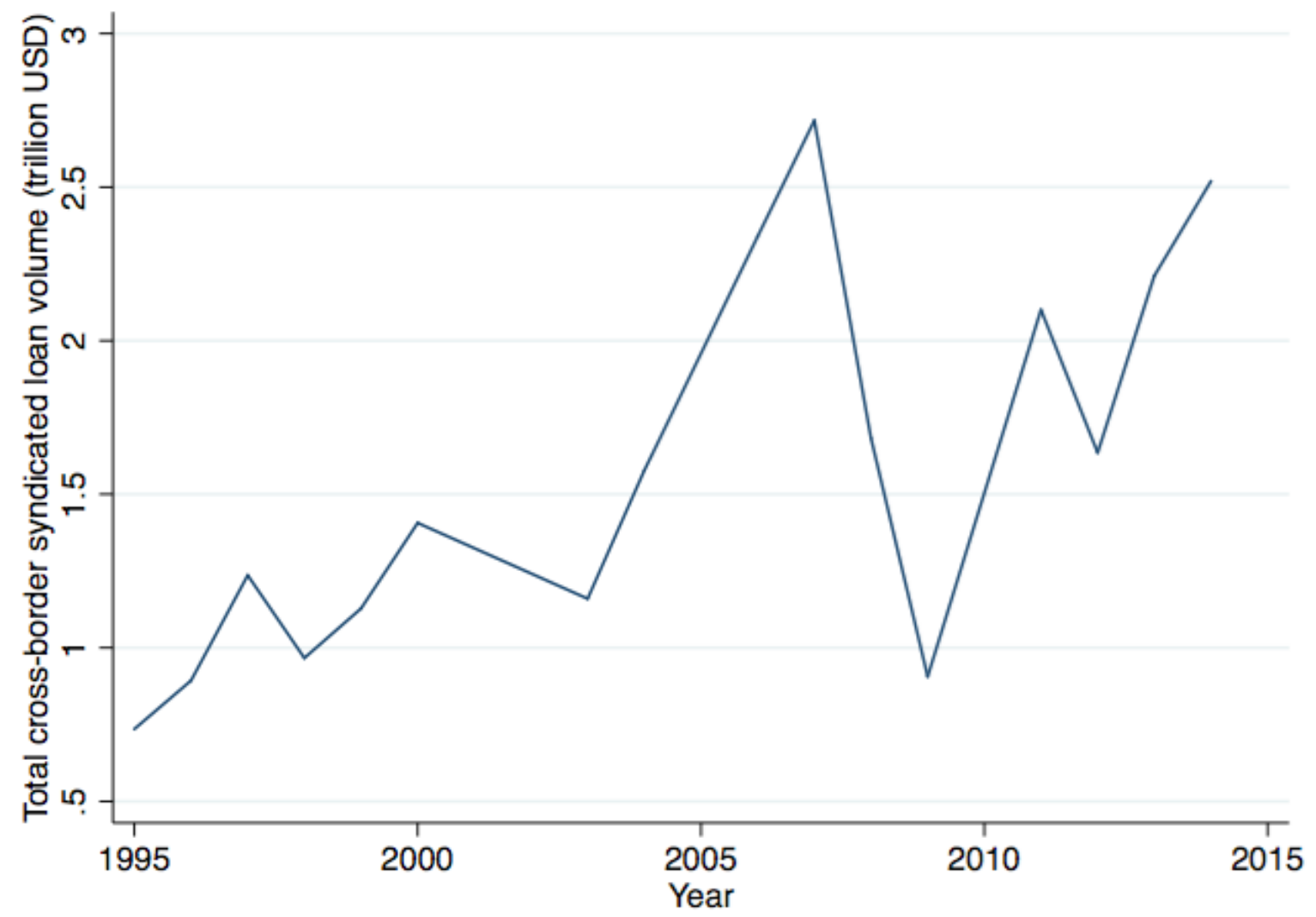

Note: This graph shows the total amount of cross-border lending to non-financial borrowers over the sample period. The graph excludes 2015 because the sample period does not cover the whole year. 


\section{Table 1: Descriptive statistics}

Volume is the natural logarithm of the dollar amount of a banks' share in a syndicated loan, aggregated at the borrower-lender-time level. Maturity is the maturity of a facility in months. Spread is the loan spread over the reference rate in basis points for drawn credit of a facility. Collateral is a dummy variable indicating that a loan is collateralized. Covenant is a dummy variable indicating that there is a net worth or financial ratio covenant in the loan contract. IR is the central bank policy rate or the discount rate in the lender's country. IR (Borrower) is IR is the central bank policy rate or the discount rate in the borrower's country. Taylor residual is a variable containing the errors from regressions of monetary policy rates (IR) in the lender's country on the real GDP growth rate and the inflation rate (CPI) separately for each lender country. QE is a dummy variable indicating that a quantitative easing program was in place in the lender's country. Borrower E/A is the book value of common equity to the book value of total assets, lagged by one year. Foreign-Owned Banks, borrower is the fraction of the banking system's assets in the borrower's country that is foreign owned, in percentage points. FDI is the number of subsidiaries in the country of the borrower owned by banks in the lender's country. Experience is the natural logarithm of $1+$ the number of loans extended by the lender in the country of the borrower in the three years prior to the loan. Subsidiaries is a dummy variable that equals one if the lender company has at least one subsidiary in the borrower country during the sample period and zero otherwise. Official Supervisory Power, borrower is an index of the power of the supervisory authorities in the borrower's country to take specific actions to prevent and correct problems in banks, with higher values indicating greater power. Overall Capital Stringency, borrower is an index measuring the stringency in determining minimum capital adequacy in the borrower's country, with higher values indicating greater stringency. Overall Restrictions on Banking Activities, borrower is an index of the extent to which banks in the borrower's country can engage in securities, insurance and real estate activities, with higher values indicating more restrictions. ER flexibility is a dummy variable indicating that the borrower's country has a flexible exchange rate regime. Credit Constraints (in) is a dummy variable indicating the presence of restrictions on the inflow of commercial credit in the borrower's country. GDP per capita is GDP per capita in constant 2005 US dollars. Credit is domestic credit to the private sector by banks as a percentage of GDP. Domestic credit is domestic credit provided by the financial sector as a percentage of GDP. Market cap is the market capitalization of listed companies as a percentage of GDP. Turnover ratio is the total value of shares traded during the period as a percentage of the average market capitalization for the period. QE is a dummy variable indicating that a quantitative easing program was in place in the lender's country. CPI is the annual percentage change of the consumer price index in the lender's country. GDP growth is the annual percentage change of real GDP in the lender's country. Except for Maturity, Spread, Collateral and Covenant, all summary statistics are for the sample used in regression 1 of Table 2. The summary statistics of Maturity, Spread, Collateral, and Covenant are for the samples used to estimate regressions 1, 3, 5, and 7 of Table 4.

\begin{tabular}{lccccc}
\hline \hline & Obs & Mean & SD & Min & Max \\
\hline Volume (in millions of USD) & 93223 & 55.638 & 72.394 & 1 & 410 \\
Volume & 93223 & 17.21 & 1.162 & 13.82 & 19.83 \\
Maturity & 65318 & 60.57 & 32.16 & 6 & 284 \\
Spread & 67704 & 245.7 & 158.4 & 15 & 825 \\
Collateral & 34243 & 0.817 & 0.387 & 0 & 1 \\
Covenant & 43390 & 0.290 & 0.454 & 0 & 1 \\
IR & 93223 & 0.0248 & 0.0214 & -0.00250 & 0.480 \\
IR (Borrower) & 82660 & 0.0393 & 0.0472 & -0.00250 & 1.500 \\
Taylor residual & 85189 & -0.00509 & 0.0171 & -0.0879 & 0.128 \\
QE & 93223 & 0.121 & 0.326 & 0 & 1 \\
Borrower E/A & 49073 & 0.387 & 0.169 & 0.0269 & 0.942 \\
Foreign-Owned Banks, borrower & 66345 & 16.51 & 19.67 & 0 & 100 \\
FDI & 93223 & 1.565 & 1.859 & 0 & 22 \\
Experience & 73540 & 4.241 & 2.101 & 0 & 7.627 \\
Subsidiaries & 93223 & 0.686 & 0.464 & 0 & 1 \\
Official Supervisory Power, borrower & 86243 & 11.69 & 2.214 & 4 & 16 \\
Overall Capital Stringency, borrower & 81954 & 4.405 & 1.611 & 0 & 7
\end{tabular}




\begin{tabular}{lccccc} 
Overall Restrictions on Banking Activities, borrower & 85760 & 7.223 & 2.133 & 3 & 12 \\
Official Supervisory Power, lender & 83646 & 10.20 & 2.333 & 4 & 16 \\
Overall Capital Stringency, lender & 84477 & 4.271 & 1.655 & 1 & 7 \\
Overall Restrictions on Banking Activities, lender & 84609 & 6.116 & 2.334 & 3 & 12 \\
ER flexibility & 70833 & 0.785 & 0.411 & 0 & 1 \\
Credit Constraints (in) & 84386 & 0.146 & 0.353 & 0 & 1 \\
GDP per capita & 90472 & 31363.3 & 16448.9 & 162.9 & 87772.7 \\
Credit & 80301 & 81.81 & 46.41 & 2.521 & 305.0 \\
Domestic credit & 80285 & 153.1 & 62.85 & -27.96 & 349.0 \\
Market cap & 80922 & 115.9 & 83.16 & 0.139 & 606.0 \\
Turnover ratio & 80880 & 119.3 & 74.77 & 0 & 497.4 \\
CPI & 93223 & 1.761 & 1.501 & -5.258 & 46.22 \\
GDP growth & 93223 & 2.382 & 2.461 & -9.274 & 19.30 \\
\hline \hline
\end{tabular}


Table 2: Monetary policy and cross-border lending volume

The dependent variable in all regressions is Volume, which is the natural logarithm of the dollar amount of a banks' share in a syndicated loan, aggregated at the borrower-lender-time level. IR is the central bank policy rate or the discount rate in the lender's country. Borrower E/A is the book value of common equity to the book value of total assets, lagged by one year. QE is a dummy variable indicating that a quantitative easing program was in place in the lender's country. CPI is the annual percentage change of the consumer price index in the lender's country. GDP growth is the annual percentage change of real GDP in the lender's country. The sample includes non-financial borrowers only. Standard errors clustered at the lender company and borrower country levels are reported in parentheses. $* * *$, and $* * *$ denote significance at $10 \%, 5 \%$, and $1 \%$.

\begin{tabular}{lcccc}
\hline \hline & $(1)$ & $(2)$ & $(3)$ & $(4)$ \\
\hline IR & -0.307 & $-1.013^{*}$ & $-0.818^{* *}$ & $-1.844^{* * *}$ \\
& $(0.264)$ & $(0.550)$ & $(0.406)$ & $(0.558)$ \\
IR * Borrower E/A & & $2.614 *$ & & $2.829 * *$ \\
& & $(1.385)$ & & $(1.334)$ \\
QE & & & $-0.0713^{* * *}$ & $-0.0862^{* * *}$ \\
& & & $(0.0269)$ & $(0.0249)$ \\
CPI & 0.00460 & 0.000431 & $0.00892^{* *}$ & 0.00401 \\
& $(0.00355)$ & $(0.00344)$ & $(0.00372)$ & $(0.00348)$ \\
GDP growth & $0.00563 * *$ & $0.00672^{* *}$ & $0.00609 * * *$ & $0.00673 * *$ \\
& $(0.00232)$ & $(0.00273)$ & $(0.00230)$ & $(0.00267)$ \\
\hline Observations & 93223 & 48959 & 93223 & 48959 \\
Adjusted R-squared & 0.813 & 0.806 & 0.813 & 0.806 \\
Borrower*Time FE & Yes & Yes & Yes & Yes \\
Lender FE & Yes & Yes & Yes & Yes \\
\hline \hline
\end{tabular}


Table 3: Taylor rule residual, QE and cross-border lending volume

The dependent variable in all regressions is Volume, which is the natural logarithm of the dollar amount of a banks' share in a syndicated loan, aggregated at the borrower-lender-time level. Taylor residual is the error from a regression of the monetary policy rates (IR) on the real GDP growth rate and the inflation rate (CPI) separately for each lender country. IR is the central bank policy rate or the discount rate in the lender's country. Borrower $\mathrm{E} / \mathrm{A}$ is the book value of common equity to the book value of total assets, lagged by one year. QE is a dummy variable indicating that a quantitative easing program was in place in the lender's country. CPI is the annual percentage change of the consumer price index in the lender's country. GDP growth is the annual percentage change of real GDP in the lender's country. The sample includes non-financial borrowers only. Standard errors clustered at the lender company and borrower country levels are reported in parentheses. *, **, and *** denote significance at $10 \%, 5 \%$, and $1 \%$.

\begin{tabular}{lcccc}
\hline \hline & $(1)$ & $(2)$ & $(3)$ & $(4)$ \\
\hline Taylor residual & -0.298 & $-1.889^{* * *}$ & $-1.075^{* * *}$ & $-2.963 * * *$ \\
& $(0.281)$ & $(0.538)$ & $(0.377)$ & $(0.618)$ \\
Taylor residual * Borrower E/A & & $3.679^{* * *}$ & & $3.779^{* * *}$ \\
& & $(1.214)$ & & $(1.184)$ \\
QE & & & $-0.0906^{* * *}$ & $-0.112^{* * *}$ \\
& & & $(0.0200)$ & $(0.0183)$ \\
CPI & 0.00294 & -0.00220 & 0.00385 & -0.00315 \\
& $(0.00356)$ & $(0.00407)$ & $(0.00335)$ & $(0.00355)$ \\
GDP growth & $0.00521^{* *}$ & $0.00688 * *$ & $0.00488^{* *}$ & $0.00548^{*}$ \\
& $(0.00242)$ & $(0.00284)$ & $(0.00240)$ & $(0.00299)$ \\
\hline Observations & 84505 & 43673 & 84505 & 43673 \\
Adjusted R-squared & 0.817 & 0.812 & 0.817 & 0.812 \\
Borrower*Time FE & Yes & Yes & Yes & Yes \\
Lender FE & Yes & Yes & Yes & Yes \\
\hline \hline
\end{tabular}


Table 4: Monetary policy and the terms of cross-border loans

The dependent variable in regressions 1 and 2 is Maturity, which is the maturity of a facility in months. The dependent variable in regressions 3 and 4 is Spread, which is the loan spread over the reference rate in basis points (for drawn credit) of a facility. The dependent variable in regressions 5 and 6 is Collateral, a dummy variable indicating that a loan is collateralized. The dependent variable in regressions 7 and 8 is Covenant, a dummy variable indicating that there is a net worth or financial ratio covenant in the loan contract. IR is the central bank policy rate or the discount rate in the lender's country. Borrower E/A is the book value of common equity to the book value of total assets, lagged by one year. QE is a dummy variable indicating that a quantitative easing program was in place in the lender's country. CPI is the annual percentage change of the consumer price index in the lender's country. GDP growth is the annual percentage change of real GDP in the lender's country. The sample includes non-financial borrowers only. Standard errors clustered at the borrower country level are reported in parentheses. *,**, and *** denote significance at $10 \%, 5 \%$, and $1 \%$.

\begin{tabular}{|c|c|c|c|c|c|c|c|c|}
\hline & \multicolumn{2}{|c|}{ Maturity } & \multicolumn{2}{|c|}{ Spread } & \multicolumn{2}{|c|}{ Collateral } & \multicolumn{2}{|c|}{ Covenant } \\
\hline & (1) & (2) & (3) & (4) & $(5)$ & (6) & (7) & $(8)$ \\
\hline \multirow[t]{2}{*}{ IR } & $-118.3 * * *$ & $-148.3^{* *}$ & $-551.8 * * *$ & $-595.7 * * *$ & $-0.656 * * *$ & $0.859 * * *$ & 0.164 & $-0.852 * * *$ \\
\hline & $(39.47)$ & $(56.53)$ & $(132.7)$ & (149.6) & $(0.163)$ & $(0.248)$ & $(0.210)$ & $(0.296)$ \\
\hline \multirow[t]{2}{*}{ IR * Borrower E/A } & & 85.08 & & $378.7 * *$ & & $-2.692 * * *$ & & -0.0123 \\
\hline & & $(76.72)$ & & (186.6) & & $(0.530)$ & & $(0.510)$ \\
\hline \multirow[t]{2}{*}{ Borrower E/A } & & $-6.244 * *$ & & $-71.81 * * *$ & & $-0.0797 * * *$ & & $0.175^{* * *}$ \\
\hline & & $(2.556)$ & & $(7.484)$ & & $(0.0183)$ & & $(0.0255)$ \\
\hline \multirow[t]{2}{*}{ QE } & $-5.440 * * *$ & $-6.522 * * *$ & $-93.36 * * *$ & $-40.72 * * *$ & $-0.184 * * *$ & $-0.0855^{* * *}$ & $0.0477 * * *$ & $-0.0667 * * *$ \\
\hline & $(1.180)$ & $(1.047)$ & $(7.290)$ & (5.302) & $(0.0232)$ & $(0.0115)$ & $(0.00822)$ & $(0.00900)$ \\
\hline \multirow[t]{2}{*}{ CPI } & -0.0602 & $0.703 *$ & $-1.324 *$ & $7.689 * * *$ & $0.0153 * * *$ & $0.0439 * * *$ & -0.00159 & $0.00959 * * *$ \\
\hline & $(0.434)$ & $(0.359)$ & $(0.774)$ & $(0.701)$ & $(0.00283)$ & $(0.00369)$ & $(0.00181)$ & $(0.00287)$ \\
\hline \multirow[t]{2}{*}{ GDP growth } & 0.185 & 0.513 & $5.859 * * *$ & $4.201 * * *$ & $0.00399 * *$ & $0.00420 *$ & -0.00440 & $-0.0107 * * *$ \\
\hline & $(0.238)$ & $(0.316)$ & $(0.862)$ & $(0.574)$ & $(0.00185)$ & $(0.00236)$ & $(0.00330)$ & $(0.00339)$ \\
\hline Observations & 92191 & 28544 & 67704 & 21756 & 44759 & 14883 & 43390 & 14288 \\
\hline Adjusted R-squared & 0.536 & 0.467 & 0.384 & 0.467 & 0.435 & 0.453 & 0.123 & 0.193 \\
\hline Borrower country - industry $*$ Time FE & Yes & Yes & Yes & Yes & Yes & Yes & Yes & Yes \\
\hline
\end{tabular}


Table 5: The role of foreign banking presence, monetary policy and cross-border lending volume

Panel A: The dependent variable in all regressions is Volume, which is the natural logarithm of the dollar amount of a banks' share in a syndicated loan, aggregated at the borrower-lender-time level. IR is the central bank policy rate or the discount rate in the lender's country. Foreign-Owned Banks, borrower is the fraction of the banking system's assets in the borrower's country that is foreign owned, in percentage points. Official Supervisory Power, borrower (lender) is an index of the power of the supervisory authorities in the borrower's (lender's) country to take specific actions to prevent and correct problems in banks, with higher values indicating greater power. Overall Capital Stringency, borrower (lender) is an index measuring the stringency in determining minimum capital adequacy in the borrower's (lender's) country, with

higher values indicating greater stringency. Overall Restrictions on Banking Activities, borrower (lender) is an index of the extent to which banks in the borrower's (lender's) country can engage in securities, insurance and real estate activities, with higher values indicating more restrictions. ER flexibility is a dummy variable indicating that the borrower's country has a flexible exchange rate regime. Credit Constraints (in) is a dummy variable indicating the presence of restrictions on the inflow of commercial credit in the borrower's country. QE is a dummy variable indicating that a quantitative easing program was in place in the lender's country. CPI is the annual percentage change of the consumer price index in the lender's country. GDP growth is the annual percentage change of real GDP in the lender's country. The sample includes non-financial borrowers only. Standard errors clustered at the lender company and borrower country levels are reported in parentheses. *, **, and $* * *$ denote significance at $10 \%, 5 \%$, and $1 \%$.

\begin{tabular}{lccc}
\hline \hline & $(1)$ & $(2)$ & $(3)$ \\
\hline IR & $-1.781^{* * *}$ & 0.356 & 1.584 \\
& $(0.605)$ & $(2.053)$ & $(1.519)$ \\
IR * Foreign-Owned Banks, borrower & $0.0527^{* * *}$ & $0.0578^{* * *}$ & $0.0492^{* * *}$ \\
& $(0.0144)$ & $(0.0161)$ & $(0.0135)$ \\
IR * Official Supervisory Power, lender & & -0.243 & \\
& & $(0.193)$ & \\
Official Supervisory Power, lender & & 0.00313 & \\
& & $(0.00404)$ & \\
IR * Overall Capital Stringency, lender & & & $-0.826 * * *$ \\
& & & $0.242)$ \\
Overall Capital Stringency, lender & & & 0.00895 \\
& & & $(0.00736)$
\end{tabular}

IR * Overall Restrictions on Banking Activities, lender 
$(0.00605)$

IR * Official Supervisory Power, borrower

IR * Overall Capital Stringency, borrower

IR * Overall Restrictions on Banking Activities, borrower

IR * ER flexibility

IR * Credit Constraints (in)

QE

CPI

GDP growth

Observions

Observations

Adjusted R-squared

Borrower*Time FE

Lender FE
0.0761

$(0.185)$

0.0213

(0.224)

$-0.0239$

$(0.227)$

$-0.231$

(0.922)

$-1.258$

(0.775)

$-0.0729 * * * \quad-0.0914 * * *$

$-0.104 * * *$

$-0.0881 * * *$

$-0.0721 * * *$

$-0.0735^{* * * *}$

$-0.0734 * * *$

$-0.0792 * * * \quad-0.0732 * * *$

(0.0224) (0.0184)

$(0.0224)$

(0.0223)

(0.0233)

(0.0231)

(0.0231)

$0.00671 \quad 0.00530$

(0.00477)

(0.00451)

(0.00445)

$(0.00443)$

0.00681

0.00421

0.00511

$(0.00449)$

0.00281

$0.00448 *$

0.00350 *

0.00291

0.00279

(0.00448)

(0.00373)

(0.00407)

$(0.00165)$

63913

$0.00294 *$

$.00397^{* * *}$

$0.00354 * *$

66276

0.800

Yes

Yes

Yes

0.803

Yes

$0.803 \quad 0.80$

$0.803 \quad 0.802$

Yes

Yes

$\begin{array}{cccc}0.803 & 0.802 & 0.796 & 0.800 \\ \text { Yes } & \text { Yes } & \text { Yes } & \text { Yes } \\ \text { Yes } & \text { Yes } & \text { Yes } & \text { Yes }\end{array}$


Panel B: The dependent variable in all regressions is Volume, which is the natural logarithm of the dollar amount of a banks' share in a syndicated loan, aggregated at the borrower-lender-time level. IR is the central bank policy rate or the discount rate in the lender's country. FDI is the number of subsidiaries in the country of the borrower owned by banks in the lender's country. Official Supervisory Power, borrower (lender) is an index of the power of the supervisory authorities in the borrower's (lender's) country to take specific actions to prevent and correct problems in banks, with higher values indicating greater power. Overall Capital Stringency, borrower (lender) is an index measuring the stringency in determining minimum capital adequacy in the borrower's (lender's) country, with higher values indicating greater stringency. Overall

Restrictions on Banking Activities, borrower (lender) is an index of the extent to which banks in the borrower's (lender's) country can engage in securities, insurance and real estate activities, with higher values indicating more restrictions. ER flexibility is a dummy variable indicating that the borrower's country has a flexible exchange rate regime. Credit Constraints (in) is a dummy variable indicating the presence of restrictions on the inflow of commercial credit in the borrower's country. QE is a dummy variable indicating that a quantitative easing program was in place in the lender's country. CPI is the annual percentage change of the consumer price index in the lender's country. GDP growth is the annual percentage change of real GDP in the lender's country. The sample includes non-financial borrowers only. Standard errors clustered at the lender company and borrower country levels are reported in parentheses. *,**, and *** denote significance at $10 \%, 5 \%$, and $1 \%$.

\begin{tabular}{|c|c|c|c|c|c|c|c|c|c|}
\hline & (1) & (2) & (3) & (4) & (5) & (6) & (7) & (8) & (9) \\
\hline \multirow[t]{2}{*}{ IR } & $-0.846^{*}$ & 0.461 & 1.681 & $-2.438 * * *$ & -0.361 & -0.463 & -0.659 & 0.480 & $-0.818^{*}$ \\
\hline & $(0.476)$ & (1.392) & (1.083) & $(0.733)$ & $(1.650)$ & $(0.839)$ & $(1.029)$ & $(0.628)$ & $(0.416)$ \\
\hline \multirow[t]{2}{*}{ IR * FDI } & 0.215 & $0.258 *$ & 0.208 & 0.177 & $0.242 *$ & $0.371 * * *$ & $0.252 *$ & $0.324 *$ & 0.190 \\
\hline & $(0.143)$ & $(0.150)$ & $(0.145)$ & $(0.151)$ & $(0.143)$ & $(0.113)$ & $(0.148)$ & $(0.175)$ & $(0.158)$ \\
\hline \multirow[t]{2}{*}{ FDI } & $0.0234 * *$ & $0.0213^{*}$ & $0.0194 *$ & $0.0235 * *$ & $0.0220 * *$ & $0.0196^{*}$ & $0.0210^{*}$ & $0.0189 *$ & $0.0294 * *$ \\
\hline & $(0.0110)$ & $(0.0111)$ & $(0.0100)$ & $(0.0112)$ & $(0.0109)$ & $(0.0105)$ & (0.0109) & $(0.0108)$ & $(0.0120)$ \\
\hline \multirow[t]{2}{*}{ IR * Official Supervisory Power, lender } & & -0.170 & & & & & & & \\
\hline & & $(0.128)$ & & & & & & & \\
\hline \multirow[t]{2}{*}{ Official Supervisory Power, lender } & & 0.00435 & & & & & & & \\
\hline & & $(0.00460)$ & & & & & & & \\
\hline \multirow[t]{2}{*}{ IR $*$ Overall Capital Stringency, lender } & & & $-0.687 * * *$ & & & & & & \\
\hline & & & $(0.191)$ & & & & & & \\
\hline \multirow[t]{2}{*}{ Overall Capital Stringency, lender } & & & 0.00521 & & & & & & \\
\hline & & & $(0.00511)$ & & & & & & \\
\hline \multirow[t]{2}{*}{ IR * Overall Restrictions on Banking Activities, lender } & & & & $0.207 *$ & & & & & \\
\hline & & & & $(0.113)$ & & & & & \\
\hline \multirow[t]{2}{*}{ Overall Restrictions on Banking Activities, lender } & & & & -0.00609 & & & & & \\
\hline & & & & $(0.00535)$ & & & & & \\
\hline
\end{tabular}


IR * Official Supervisory Power, borrower

IR * Overall Capital Stringency, borrower

IR * Overall Restrictions on Banking Activities, borrower

IR $*$ ER flexibility

$\mathrm{IR} *$ Credit Constraints (in)

\begin{tabular}{|c|c|c|c|c|c|c|c|c|c|}
\hline $\mathrm{QE}$ & $\begin{array}{c}-0.0578 * * \\
(0.0258)\end{array}$ & $\begin{array}{c}-0.0901 * * * \\
(0.0210)\end{array}$ & $\begin{array}{c}-0.0973 * * * \\
(0.0232)\end{array}$ & $\begin{array}{c}-0.0804 * * * \\
(0.0267)\end{array}$ & $\begin{array}{c}-0.0577 * * \\
(0.0282)\end{array}$ & $\begin{array}{l}-0.0508^{*} \\
(0.0278)\end{array}$ & $\begin{array}{c}-0.0597 * * \\
(0.0296)\end{array}$ & $\begin{array}{c}-0.0783 * * * \\
(0.0219)\end{array}$ & $\begin{array}{c}-0.0634 * * * \\
(0.0238)\end{array}$ \\
\hline \multirow[t]{2}{*}{ CPI } & $0.00764 * *$ & 0.00562 & 0.000469 & 0.00378 & $0.00866^{* *}$ & $0.00804 *$ & $0.00938 * *$ & 0.00322 & 0.00469 \\
\hline & $(0.00368)$ & $(0.00394)$ & $(0.00480)$ & $(0.00407)$ & $(0.00404)$ & $(0.00431)$ & $(0.00412)$ & $(0.00356)$ & $(0.00366)$ \\
\hline \multirow[t]{2}{*}{ GDP growth } & $0.00552 * * *$ & $0.00497 * *$ & $0.00791 * * *$ & $0.00678 * * *$ & $0.00626 * * *$ & $0.00489 * * *$ & $0.00594 * * *$ & $0.00628 * * *$ & $0.00634 * * *$ \\
\hline & $(0.00207)$ & $(0.00226)$ & $(0.00242)$ & $(0.00218)$ & $(0.00208)$ & $(0.00182)$ & $(0.00206)$ & $(0.00194)$ & $(0.00207)$ \\
\hline Observations & 93223 & 83216 & 84179 & 84288 & 86213 & 81919 & 85730 & 70772 & 84349 \\
\hline Adjusted R-squared & 0.814 & 0.811 & 0.813 & 0.814 & 0.814 & 0.809 & 0.814 & 0.810 & 0.811 \\
\hline Borrower*Time FE & Yes & Yes & Yes & Yes & Yes & Yes & Yes & Yes & Yes \\
\hline Lender FE & Yes & Yes & Yes & Yes & Yes & Yes & Yes & Yes & Yes \\
\hline
\end{tabular}

$-0.0636$

$(0.142)$

$-0.183$

$(0.182)$

$-0.0610$

$(0.115)$

$-1.821 * * *$

$(0.623)$

$-0.349$

0.777 
Panel C: The dependent variable in all regressions is Volume, which is the natural logarithm of the dollar amount of a banks' share in a syndicated loan, aggregated at the borrower-lender-time level. IR is the central bank policy rate or the discount rate in the lender's country. Foreign-Owned Banks, borrower is the fraction of the banking system's assets in the borrower's country that is foreign owned, in percentage points. FDI is the number of subsidiaries in the country of the borrower owned by banks in the lender's country. GDP per capita is GDP per capita in constant 2005 US dollars. Credit is domestic credit to the private sector by banks as a percentage of GDP. Domestic credit is domestic credit provided by the financial sector as a percentage of GDP. Market cap is the market capitalization of listed companies as a percentage of GDP.

Turnover ratio is the total value of shares traded during the period as a percentage of the average market capitalization for the period. QE is a dummy variable indicating that a quantitative easing program was in place in the lender's country. CPI is the annual percentage change of the consumer price index in the lender's country. GDP growth is the annual percentage change of real GDP in the lender's country. The sample includes non-financial borrowers only. Standard errors clustered at the lender company and borrower country levels are reported in parentheses. *,**, and *** denote significance at $10 \%, 5 \%$, and $1 \%$.

\begin{tabular}{lccccc}
\hline \hline & $(1)$ & $(2)$ & $(3)$ & $(4)$ & $(5)$ \\
\hline IR & $-2.930^{* * *}$ & $-2.276^{* *}$ & $-3.583^{* * *}$ & $-2.919^{* * *}$ & $-2.761^{* * *}$ \\
& $(0.716)$ & $(0.914)$ & $(1.019)$ & $(0.736)$ & $(0.591)$ \\
IR * Foreign-Owned Banks, borrower & $0.0563^{* * *}$ & $0.0435^{* *}$ & $0.0617 * * *$ & $0.0495^{* *}$ & $0.0584 * * *$ \\
& $(0.0177)$ & $(0.0169)$ & $(0.0213)$ & $(0.0212)$ & $(0.0177)$ \\
IR * FDI & & & & &
\end{tabular}

$\begin{array}{ll} & \\ \text { IR * GDP per capita } & 0.0000450 * \\ & (0.0000250)\end{array}$

$\begin{array}{lcccc}0.205 & 0.234 & 0.201 & 0.189 & 0.211 \\ (0.141) & (0.168) & (0.152) & (0.155) & (0.164)\end{array}$

0.0000199

$(0.0000165)$

IR * Credit

0.0112

0.00886

$(0.00869)$

$(0.00804)$

IR * Domestic credit

$0.0139 * *$

0.00332

$(0.00639)$

(0.00504)

$0.0138^{* *}$

$0.00391^{*}$

$(0.00623)$

$(0.00210)$

$0.0101 * * *$

(0.00344) (0.00280)

$\begin{array}{lllll}0.0240 * * & 0.0221^{*} & 0.0233^{* *} & 0.0237 * * & 0.0236 *\end{array}$

$\begin{array}{lllll}(0.0113) & (0.0117) & (0.0117) & (0.0116) & (0.0119)\end{array}$




\begin{tabular}{|c|c|c|c|c|c|c|c|c|c|c|}
\hline $\mathrm{QE}$ & $\begin{array}{c}-0.0668 * * * \\
(0.0226)\end{array}$ & $\begin{array}{c}-0.0743 * * * \\
(0.0238)\end{array}$ & $\begin{array}{c}-0.0655^{* *} \\
(0.0250)\end{array}$ & $\begin{array}{c}-0.0719 * * * \\
(0.0232)\end{array}$ & $\begin{array}{c}-0.0685^{* * *} \\
(0.0247)\end{array}$ & $\begin{array}{c}-0.0539 * * \\
(0.0247)\end{array}$ & $\begin{array}{c}-0.0714 * * * \\
(0.0244)\end{array}$ & $\begin{array}{c}-0.0721 * * * \\
(0.0235)\end{array}$ & $\begin{array}{c}-0.0716 * * * \\
(0.0233)\end{array}$ & $\begin{array}{c}-0.0709 * * * \\
(0.0235)\end{array}$ \\
\hline \multirow[t]{2}{*}{ CPI } & 0.00601 & 0.00476 & 0.00492 & 0.00491 & 0.00356 & $0.00686^{* *}$ & 0.00432 & 0.00429 & 0.00445 & 0.00435 \\
\hline & $(0.00407)$ & $(0.00401)$ & $(0.00387)$ & $(0.00387)$ & $(0.00389)$ & $(0.00341)$ & $(0.00361)$ & $(0.00359)$ & $(0.00361)$ & $(0.00359)$ \\
\hline \multirow[t]{2}{*}{ GDP growth } & $0.00279^{*}$ & $0.00327 * *$ & $0.00280^{*}$ & $0.00296 * *$ & $0.00317 * *$ & $0.00564 * * *$ & $0.00577 * * *$ & $0.00566^{* * * *}$ & $0.00569 * * *$ & $0.00584 * * *$ \\
\hline & $(0.00166)$ & $(0.00156)$ & $(0.00156)$ & $(0.00126)$ & $(0.00139)$ & $(0.00214)$ & $(0.00208)$ & $(0.00210)$ & $(0.00212)$ & $(0.00213)$ \\
\hline Observations & 64771 & 60034 & 60034 & 60213 & 60192 & 90460 & 80244 & 80226 & 80868 & 80824 \\
\hline Adjusted R-squared & 0.802 & 0.801 & 0.801 & 0.801 & 0.801 & 0.813 & 0.813 & 0.813 & 0.813 & 0.813 \\
\hline Borrower*Time FE & Yes & Yes & Yes & Yes & Yes & Yes & Yes & Yes & Yes & Yes \\
\hline Lender FE & Yes & Yes & Yes & Yes & Yes & Yes & Yes & Yes & Yes & Yes \\
\hline
\end{tabular}


Table 6: Lending experience in borrower countries and the role of subsidiaries

The dependent variable in all regressions is Volume, which is the natural logarithm of the dollar amount of a banks' share in a syndicated loan, aggregated at the borrowerlender-time level. IR is the central bank policy rate or the discount rate in the lender's country. Foreign-Owned Banks, borrower is the fraction of the banking system's assets in the borrower's country that is foreign owned, in percentage points. FDI is the number of subsidiaries in the country of the borrower owned by banks in the lender's country. Experience is the natural logarithm of $1+$ the number of loans extended by the lender in the country of the borrower in the three years prior to the loan. Subsidiaries is a dummy variable that equals one if the lender company has at least one subsidiary in the borrower country during the sample period and zero otherwise. QE is a dummy variable indicating that a quantitative easing program was in place in the lender's country. CPI is the annual percentage change of the consumer price index in the lender's country. GDP growth is the annual percentage change of real GDP in the lender's country. The sample includes non-financial borrowers only. In regressions 8 and 9 lending by foreign subsidiaries is not assigned to their parent companies and for these lenders IR is taken to be the host country monetary policy interest rate. Standard errors clustered at the lender company and borrower country levels are reported in parentheses. *,*, and *** denote significance at $10 \%, 5 \%$, and $1 \%$.

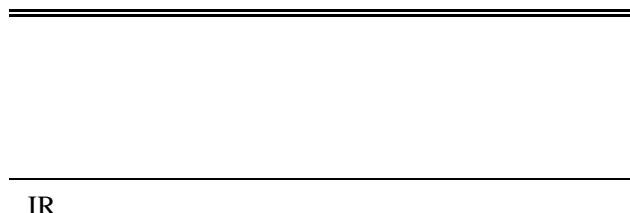

IR * Foreign-Owned Banks, borrowe

IR * FDI

IR * Experience

IR * Subsidiaries

IR * Subsidiaries * Foreign-Owned Banks, borrower

$\mathrm{IR} *$ Subsidiaries * FDI
Baseline sample

$\begin{array}{ccc}(1) & (2) & (3) \\ -0.526 & 1.189 * & -0.972 \\ (0.906) & (0.647) & (0.603)\end{array}$

$0.0272 *$

(0.0147)

$0.183^{*}$

(0.108)

$0.219 * \quad-0.0706$

(0.123) (0.114)

(0.451)

0.639

(0.513)

0.821

(0.580)

$-0.00655$

$(0.0260)$
Subsidiaries and parent separately

$\begin{array}{cc}(4) & (5) \\ -2.157 * * * & -2.268 * * * \\ (0.693) & (0.712) \\ 0.0508^{* * *} & 0.0531^{* * *} \\ (0.0146) & (0.0153) \\ & \\ & \\ & \\ 0.639 & 0.821 \\ (0.513) & (0.580) \\ & -0.00655 \\ & (0.0260)\end{array}$

$(8)-(9)$

$\begin{array}{cc}(6) & (7) \\ -1.009 & -1.177^{*}\end{array}$

$-1.208^{* * *}-0.633^{* *}$

(0.619)

(0.652)

(0.452)

$(0.283)$

$0.0381 * *$

(0.0146)

$0.222 \quad 0.534^{* *} \quad 0.237^{* *}$

$(0.143) \quad(0.213)$

(0.0950)

Exper

$0.113^{* * *} \quad 0.119^{* * * *}$ 


\section{Subsidiaries}

Subsidiaries * Foreign-Owned Banks, borrower

\section{Subsidiaries * FDI}

FDI

CPI

GDP growth

Observations

Adjusted R-squared

Borrower*Time FE

Lender FE
$(0.00820) \quad(0.00921)$

$\begin{array}{ccccc}0.0739^{* * *} & 0.0684^{* * *} & 0.0484 * * & 0.0589^{* * *} & 0.0452^{* * *} \\ (0.0182) & (0.0179) & (0.0234) & (0.0144) & (0.0154) \\ & & 0.000937 & & \end{array}$

(0.000846)

\begin{tabular}{lcccc} 
& $0.0148^{*}$ & & \\
& & $(0.00844)$ & & \\
& $0.0208^{*}$ & 0.00951 & & $0.0170^{* *}$ \\
& $(0.0110)$ & $(0.0106)$ & & $(0.00837)$ \\
0.00696 & $0.00781^{* *}$ & $0.00755^{* *}$ & 0.00152 & 0.00129 \\
$0.00433)$ & $(0.00365)$ & $(0.00367)$ & $(0.00320)$ & $(0.00312)$ \\
0.00262 & $0.00548^{* * *}$ & $0.00542^{* * *}$ & 0.00236 & 0.00212 \\
$0.00180)$ & $(0.00205)$ & $(0.00204)$ & $(0.00227)$ & $(0.00224)$ \\
$0695^{* * *}$ & $-0.0558^{* *}$ & $-0.0561^{* *}$ & $-0.0603^{* * *}$ & $-0.0519^{* * *}$ \\
$0.0213)$ & $(0.0254)$ & $(0.0248)$ & $(0.0182)$ & $(0.0146)$ \\
\hline 66276 & 93223 & 93223 & 56883 & 79586 \\
0.803 & 0.814 & 0.814 & 0.816 & 0.823 \\
Yes & Yes & Yes & Yes & Yes \\
Yes & Yes & Yes & Yes & Yes \\
\hline
\end{tabular}


Table 7: The role of lending by subsidiaries and local interest rates

The dependent variable in all regressions is Volume, which is the natural logarithm of the dollar amount of a banks' share in a syndicated loan, aggregated at the borrowerlender-time level. IR is the central bank policy rate or the discount rate in the lender's country. IR (Borrower) is the central bank policy rate or the discount rate in the

borrower's country. Foreign-Owned Banks, borrower is the fraction of the banking system's assets in the borrower's country that is foreign owned, in percentage points. FDI is the number of subsidiaries in the country of the borrower owned by banks in the lender's country. $Q E$ is a dummy variable indicating that a quantitative easing program was in place in the lender's country. CPI is the annual percentage change of the consumer price index in the lender's country. GDP growth is the annual percentage change of real GDP in the lender's country. The sample includes non-financial borrowers only. In regressions 6 and 7 foreign subsidiaries' domestic lending is excluded. Standard errors clustered at the lender company and borrower country levels are reported in parentheses. $* * *$, and $* * *$ denote significance at $10 \%, 5 \%$, and $1 \%$.

\begin{tabular}{|c|c|c|c|c|c|c|c|}
\hline & \multicolumn{5}{|c|}{ Baseline sample } & \multicolumn{2}{|c|}{$\begin{array}{c}\text { Subsidiaries' domestic lending } \\
\text { excluded }\end{array}$} \\
\hline & $(1)$ & $(2)$ & (3) & (4) & $(5)$ & $(6)$ & $(7)$ \\
\hline IR & $\begin{array}{l}0.0394 \\
(0.414)\end{array}$ & $\begin{array}{l}-0.518 \\
(0.644)\end{array}$ & $\begin{array}{l}-0.177 \\
(0.953)\end{array}$ & $\begin{array}{c}0.122 \\
(0.413)\end{array}$ & $\begin{array}{l}-0.0180 \\
(0.428)\end{array}$ & $\begin{array}{c}-1.768 * * * \\
(0.562)\end{array}$ & $\begin{array}{l}-0.856^{*} \\
(0.441)\end{array}$ \\
\hline IR * Foreign-Owned Banks, borrower & & $\begin{array}{c}0.0560^{* * *} \\
(0.0235)\end{array}$ & $\begin{array}{c}0.0443 \\
(0.0292)\end{array}$ & & & $\begin{array}{c}0.0464 * * * \\
(0.0161)\end{array}$ & \\
\hline $\mathrm{IR} * \mathrm{FDI}$ & & & & $\begin{array}{l}0.0784 \\
(0.127)\end{array}$ & $\begin{array}{c}0.287 \\
(0.190)\end{array}$ & & $\begin{array}{c}0.193 \\
(0.137)\end{array}$ \\
\hline IR * IR (Borrower) & $\begin{array}{l}-7.521 \\
(4.581)\end{array}$ & $\begin{array}{r}-12.28 * \\
(6.742)\end{array}$ & $\begin{array}{l}-18.24 \\
(13.60)\end{array}$ & $\begin{array}{l}-5.555^{*} \\
(3.312)\end{array}$ & $\begin{array}{l}-3.210 \\
(3.577)\end{array}$ & & \\
\hline IR * IR (Borrower) * Foreign-Owned Banks, borrower & & & $\begin{array}{c}0.185 \\
(0.270)\end{array}$ & & & & \\
\hline $\mathrm{IR} * \mathrm{IR}$ (Borrower) * FDI & & & & & $\begin{array}{l}-3.505 * \\
(2.029)\end{array}$ & & \\
\hline IR (Borrower) * FDI & & & & & $\begin{array}{l}0.00838 \\
(0.0757)\end{array}$ & & \\
\hline FDI & & & & $\begin{array}{c}0.0274 * * \\
(0.0113)\end{array}$ & $\begin{array}{l}0.0265^{*} \\
(0.0147)\end{array}$ & & $\begin{array}{l}0.0183 * \\
(0.0102)\end{array}$ \\
\hline CPI & $\begin{array}{c}0.00964 * * \\
(0.00368)\end{array}$ & $\begin{array}{l}0.00755^{*} \\
(0.00445)\end{array}$ & $\begin{array}{l}0.00706^{*} \\
(0.00416)\end{array}$ & $\begin{array}{c}0.00772 * * \\
(0.00350)\end{array}$ & $\begin{array}{c}0.00790^{* *} \\
(0.00345)\end{array}$ & $\begin{array}{c}0.00861 * * \\
(0.00413)\end{array}$ & $\begin{array}{l}0.00775^{*} \\
(0.00423)\end{array}$ \\
\hline GDP growth & $0.00715^{* * *}$ & $0.00384 * *$ & $0.00383 * *$ & $0.00641 * * *$ & $0.00640^{* * * *}$ & $0.00453 *$ & $0.00660 * * *$ \\
\hline
\end{tabular}




\begin{tabular}{|c|c|c|c|c|c|c|c|}
\hline \multirow{3}{*}{ QE } & $(0.00252)$ & $(0.00149)$ & $(0.00149)$ & $(0.00221)$ & $(0.00224)$ & $(0.00234)$ & $(0.00244)$ \\
\hline & $-0.0600 * *$ & $-0.0592 * *$ & $-0.0578 * *$ & $-0.0482 * *$ & $-0.0464 *$ & $-0.0816^{* * *}$ & $-0.0583 * * *$ \\
\hline & $(0.0257)$ & $(0.0228)$ & $(0.0228)$ & $(0.0234)$ & $(0.0240)$ & $(0.0183)$ & $(0.0215)$ \\
\hline Observations & 82622 & 58562 & 58562 & 82622 & 82622 & 57151 & 79664 \\
\hline Adjusted R-squared & 0.808 & 0.794 & 0.794 & 0.810 & 0.810 & 0.814 & 0.821 \\
\hline Borrower*Time FE & Yes & Yes & Yes & Yes & Yes & Yes & Yes \\
\hline Lender FE & Yes & Yes & Yes & Yes & Yes & Yes & Yes \\
\hline
\end{tabular}

